LSE 'Europe in Question’ Discussion Paper Series

\title{
Europe: From emancipation to empowerment
}

Alexander Somek

LEQS Paper No. 60/2013

April 2013

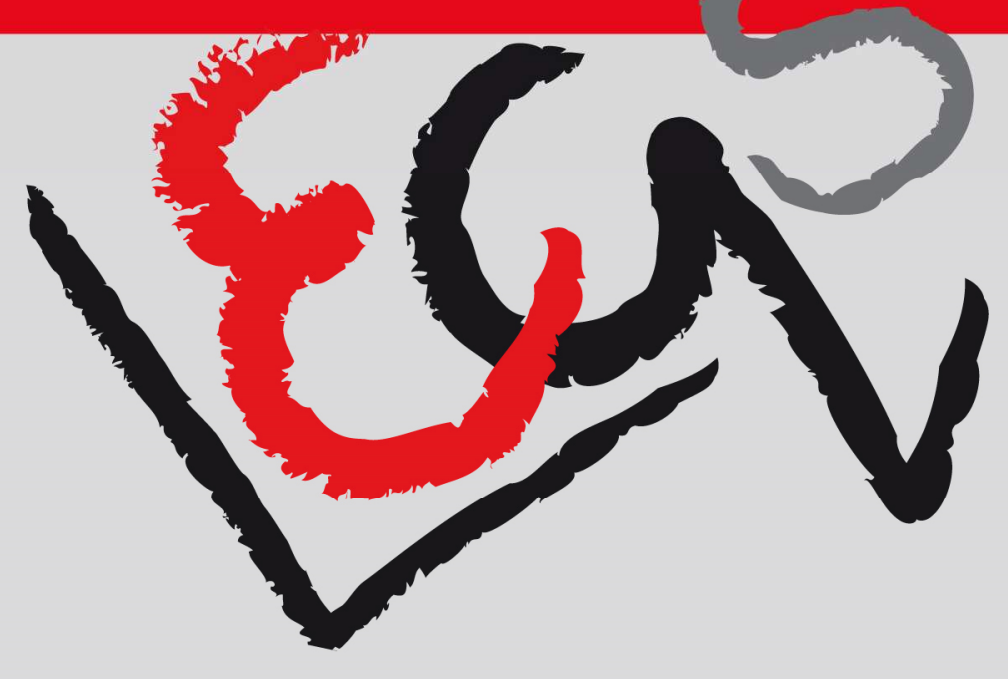




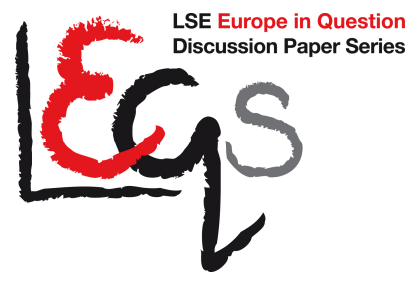

\author{
Editorial Board \\ Dr Mareike Kleine \\ Dr Vassilis Monastiriotis \\ Dr Jonathan White \\ Dr Katjana Gattermann
}

All views expressed in this paper are those of the author and do not necessarily represent the views of the editors or the LSE.

(C) Alexander Somek 


\title{
Europe: From emancipation to empowerment
}

\section{Alexander Somek ${ }^{*}$}

\begin{abstract}
Marx is dead. But so is Hayek. With neoliberalism crumbling, Europeans are beginning to wonder what it is that is really wrong with the current European Union. The paper proposes the following answer: To this day, European integration has not been a process of emancipation. This shortcoming, however, is not written on the Union's face. It requires, pursuant to best psychological traditions, a careful analysis of symptoms. One indication of the absence of emancipation is, indeed, the Union's rhetorical embrace of empowerment.
\end{abstract}

Keywords: European Integration, Economic Liberalism, Emancipation, Socialism, De-commodification, Individualism, Empowerment

* Princeton University

Visiting Research Fellow, Program in Law and Public Affairs, 413 Robertson Hall,

Princeton NJ 08544-1013

Email: asomek@Princeton.edu 


\section{Table of Contents}

Abstract

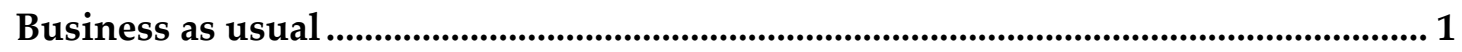

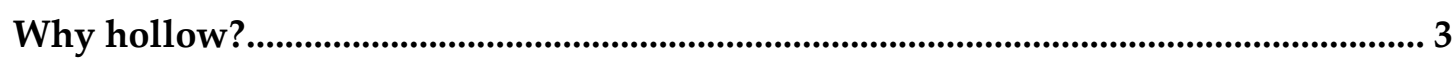

Why emancipation? - Historical consciousness .......................................................... 7

Why emancipation? - The genus of all deficits .................................................................. 10

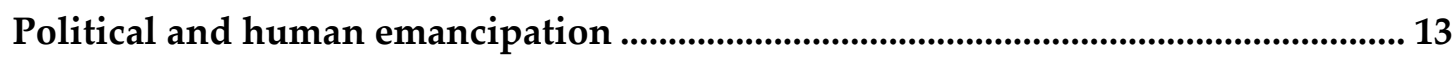

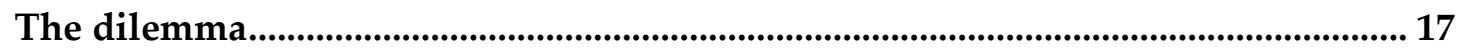

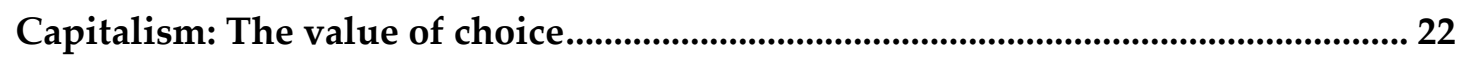

Politics and the rule of the few ............................................................................................ 25

Nobody's responsibility.......................................................................................................... 27

Private collective self-determination ...................................................................... 30

The impression of naturalness and the improvement imperative............................. 32

The world of individuals ..................................................................................................... 34

Hegel's insight: Authority by virtue of necessity............................................................... 36

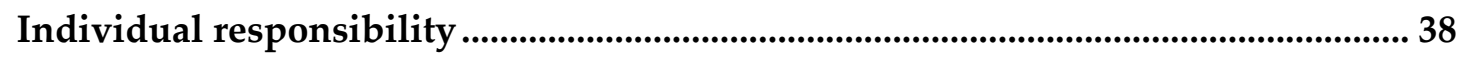

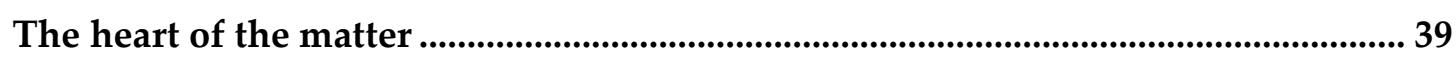

The mute point of economic liberalism ........................................................................ 42

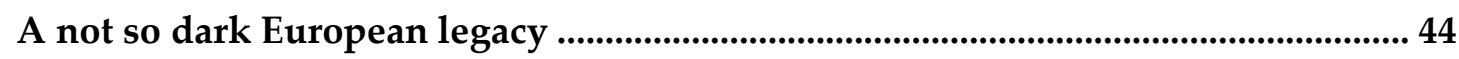

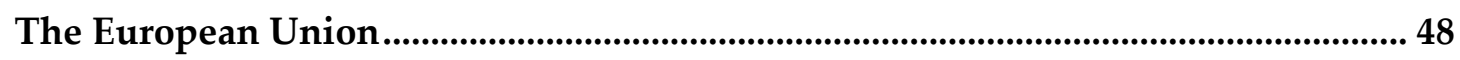

Empowerment light................................................................................................................. 51

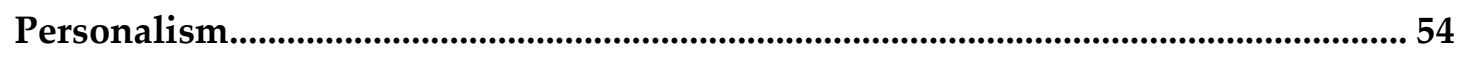

The Burkean individualist..................................................................................................... 56

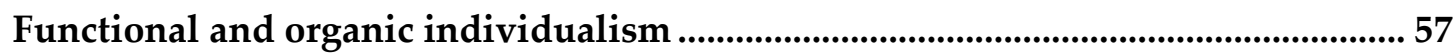

Full-bodied empowerment .......................................................................................................... 61

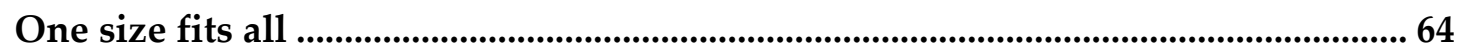

Empowerment in the European Union..............................................................................6 67

Conclusion: From Rosa Luxemburg to Steven Jobs............................................................ 71 


\section{Europe: From emancipation to empowerment}

\section{Business as usual}

Insiders of European Union studies may have already come up with a guess about what a contribution bearing this title is going say. Here is what I suspect them to suspect:

The Union is based on the respect for the individual. This is reflected, not least, in an outstanding record of individual rights protection.

Throughout the first five decades of European integration the protection of rights has been testament to a process of emancipation.

Emancipation means to accord equal status to formerly marginalized groups. Their members are enabled to participate without stigmatization or discrimination in open processes of social co-operation. ${ }^{1}$

Above all, the Union has emancipated individuals from the confines of nationality. It has created a zone without internal frontiers within which all Europeans are able to pursue their opportunities without regard to their nationality.

What is more, as an agent of emancipation the Union has made enormous progress in the field of sex equality. It has also improved the situation of other disadvantaged groups by combating discrimination on the grounds of race, disability or sexual orientation.

Of course, the process of emancipation has not come to an end. New challenges arise quickly in a dynamic and ever faster changing society. One of the greatest challenges confronting the Union today is to develop a satisfactory solution to the problem of admitting third country nationals. The Union perceives this

\footnotetext{
${ }^{1}$ It is not at all implausible to arrive at such an understanding of emancipation on the basis of the existing historical record. Emancipation does not have to stem from one's own effort at liberation. It can be granted from above. Its focus often rests on attaining equality of status or equal rights. It does not have to concern humanity at large. It may concern particular groups of society that have suffered from oppression. See Karl Martin Grass \& Reinhart Koselleck, 'Emanzipation' In O. Brunner \& W. Conze \& R. Koselleck (eds,) Geschichtliche Grundbegriffe, vol. 2 (Stuttgart: Ernst Klett Verlag, 1975) 153-197 at 169.
} 
challenge as an opportunity to develop innovative solutions on the basis of innovative strategies of policy definition, such as the Open Method of Co-ordination.

Nonetheless, the Union has already ventured beyond the traditional quest for emancipation. It has expressed ever more radically its commitment to the individual. Human well being and flourishing are no longer seen as dependent only on the emancipation of groups. The focus now comes to rest on empowerment. For example, a recent Commission Staff Working Paper explains that "the 2007-2013 EU Consumer Strategy set the aim of empowering EU consumers to help them maximize their welfare, as well as to drive competition and innovation". 2 Empowerment pushes the advancement of freedom beyond the creation and effective protection of equal rights. It aims at enhancing, in this case, the consumers" "skills, knowledge and assertiveness". Empowerment denotes selfreliance, for example, the ability to assert one's interest vis-àvis businesses that seek to reap an unfair advantage of existing complexity and ignorance.

Empowerment also means to get European citizens involved in creating the social world that they are going to inhabit in the future. The revised approach to renewing the European social market economy 3 is determined to mobilize the people's creativity and to have them involved in processes and projects of social innovation. ${ }^{4}$ In this context, empowerment means, first, to address, vigorously and in the spirit of solidarity, ${ }^{5}$ social risks with stakeholders-and not merely for them-with the aim, second, to put citizens in a position in which they can avail of the human and social capital necessary to lead successful lives in a competitive world that confronts them with increasing demands concerning flexibility. ${ }^{6}$ If coupled with the right strategies for social innovation, (e.g., social enterprises), social empowerment will turn out to be "one of the main drivers of economic growth"7.

Much has been accomplished during the last decades. The age of emancipation is not over. At the same time, in the face of the most serious economic crisis since the great depression, equal

\footnotetext{
2 European Commission, 'Consumer Empowerment in the EU', http://ec.europa.eu/consumers/consumer empowerment/docs/swd consumer empowerment eu e n.pdf at 1 .

${ }^{3}$ See Renewed Social Agenda, http://ec.europa.eu/social/main.jsp?catId=547.

4 See the study prepared by the Bureau of European Policy Advisers, which is part of the Commission bureaucracy, entitled Empowering people, driving change: Social innovation in the European Union, http://ec.europa.eu/bepa/pdf/publications_pdf/social_innovation.pdf at 57.

${ }^{5}$ See ibid. at 31.

${ }^{6}$ See ibid. at $15,27$.

7 Ibid. at 19.
} 
rights are not enough. The Union needs to advance towards the social empowerment of the individual.

The following contribution abstains from elaborating further what I have just sketched. Rather, it will try to explain why a story of this type would be remarkably hollow-even though, as the cited study suggests, it cannot be ruled out that some version of it has been already told by some pundit catering to the Union's insatiable appetite for self-aggrandizement.

\section{Why hollow?}

The explanation for why such a story would be hollow is, in part, quite straightforward.

First, affording special protection from discrimination is not an act of emancipation. It is not tantamount to releasing someone from a status of legal subordination. Rather, it helps to sustain equality of status by raising the standard of scrutiny and mitigating the effects of inequality of condition or widespread prejudice. Homosexuals are neither disenfranchised nor the servants of some master. ${ }^{8}$ They are equal citizens. Nevertheless, they have to enjoy protection from discrimination in order to be able to assert their equal status in various social settings. Likewise, being a foreigner does not imply second-class status with regard to civil rights. It merely means that in a narrow set of circumstances the fact that one is not a citizen may justify unequal treatment. Again, introducing protection against discrimination helps to make sure that cases of unequal treatment will be rare because of the scrutiny applied to the reasons claimed in its defense.

${ }^{8}$ In a legal context, in particular, "emancipation" signifies the release from servitude, tutelage or bondage. See Grass \& Koselleck, note 1 at 161. 
Second, it would be a stretch to claim that the major beneficiaries of the European Union belong to a class to which one would refer as "the excluded" or "underdogs". ${ }^{9}$ The Union is tailored to the interests of well-educated and mobile people. Their vitality has accelerated the pace of the economy and therefore by no means mitigated the hardship of those who live more rooted lives and belong to the less ambitious part of the work force. It cannot be said, at any rate, that this latter group of Europeans has in any meaningful sense of the term experienced European integration as a process of "emancipation".

Third, even though there is often widespread enthusiasm about accession to the Union among the people of accession candidate countries, it would be rather bold to say that this affirmative attitude is an outgrowth of a desire for emancipation. The reasons for accession are more mundane and, I surmise, sometimes even curious. Accession can be quite plausibly seen as a route to greater welfare, which is, nonetheless, also paved with more arduous business conditions. Accession is also an important token for being recognized as a European society in good standing. Paradoxically, being part of the Union engages national pride. This points to another reason that very plausibly underpins a pro-attitude toward the European Union. Membership pays what can be called an "imperial dividend". If one is part of the European Union one is part of something that matters on a global scale. No matter what may happen to one in life, one is still part of something that is surrounded by an elusive ring of grandeur.

Not all of these reasons may be indeed "good" reasons for joining the Union. It may also, in special instances, be the case that accession is seen as a means to escape from the trappings of one's national culture. Nevertheless, it would strike me as rather odd if people, unless they are entrepreneurs, claimed that

\footnotetext{
${ }^{9}$ See Giandomenico Majone, Europe as the Would-be World Power: The EU at Fifty (Cambridge: Cambridge University Press, 2009) at 147-148.
} 
their country's accession to the Union would mark a major step of emancipation. ${ }^{10}$

It may be objected that the Union has indeed improved the situation of citizens since it has some powers to protect them against the follies of their own governments. The Stability and Growth Pact seeks to make sure that governments behave fiscally responsibly. The serious concern that the Commission has repeatedly expressed over the Orban and Ponta governments underscores the Union's vigilance with regard to human rights and the rule of law. But what the Union system does here is to add another layer of protection on top of the national system of separation of powers. It extends checks and balances to the transnational sphere. In no manner does this go beyond the constitutional ideas governing the national level.

In what follows, I would like to explain that the Union's embrace of empowerment is indeed a symptom of the absence of emancipation; or, more precisely, of its subordination to the imperatives of economic performance. The Union does not emancipate for the simple reason that it has always been organized as a market economy. This is my thesis. Admittedly, the argument made to support it will reflect a certain, albeit uncertain, Marxist sensibility.

More precisely, reading the embrace of empowerment as signifying a dearth of freedom is the short story. It is enveloped in a longer story, which concerns the problem of liberalism. This problem is nothing short of "the" problem that liberalism has with itself. It is manifest in the disturbing fact that it is difficult to be free in a liberal society. The veritable perplexity arises from a persistent mismatch between "modern" and "ancient" liberty. ${ }^{11}$ Modern liberty is freedom enjoyed in relative independence from others. It is essentially

\footnotetext{
10 Only for the entrepreneurial class is liberalization also liberation. Perhaps it would even be more accurate in their case to speak of empowerment. I shall return to this point below.

${ }^{11}$ I am obviously borrowing the terms from Benjamin Constant. See his Political Writings (trans. Biancamaria Fontana, Cambridge: Cambridge University Press 1988) at 310-311.
} 
private. It is prone, however, to lead to the subtle authoritarianism that comes in the twin forms of market pressures and expedient administrative intervention. ${ }^{12}$ The chains of mutual interdependence and benevolent control could only be broken if modern liberty were to transcend itself into its ancient counterpart, which is ethically far more demanding-and decidedly less "nice"13-than its modern political equivalent. ${ }^{14}$ Ancient liberty means subjection to the common will in whose formation one actively participates. ${ }^{15}$ It is essentially public.

The link between emancipation and common control has been insinuated by Marx's vision of "human emancipation". Alas, it is not easily available to us moderns ${ }^{16}$ who are, as Constant correctly observed, "far more attached than the ancients to our individual independence" ${ }^{17}$ Since we are, therefore, more likely to sacrifice public to private liberty for the simple reason that we believe this trade-off to be more beneficial than the reverse, we are also likely to remain stuck in a situation where we succumb to control by subtle forces, be these markets or the obscure operation of some standard-setting and regulating agencies. The dilemma that in its private and its public form freedom is potentially self-subversive ${ }^{18}$ is the upshot of the problem of liberalism. Arguably, representative democracy marks the path towards its solution.

\footnotetext{
12 Of the latter threat Benjamin Constant had been acutely aware. See Jeremy Jennings, 'Constant's Idea of Modern Liberty' In The Cambridge Companion to Constant (ed. H. Rosenblatt, Cambridge: Cambridge University Press, 2009) 69-91 at 73.

13 See, in particular, on ostracism, Stephen Holmes, 'The Liberty to Denounce: Ancient and Modern' In Companion, note 12, 47-68 at 60

14 See Constant, note 11 at 325-327.

${ }^{15}$ See ibid. at 311.

16 See the perceptive observation by Holmes, note 13 at 51, that "freedom" as envisaged by Constant does not include the freedom to choose the type of freedom that one desires.

17 See ibid. at 317.

18 The dilemma can also be described as a conflict of the „enabling conditions of self-assertion“. Participation in group life is both a condition and a threat to human freedom. See Roberto Mangabeira Unger. False Necessity (Cambridge: Cambridge University Press, 1987) at 104-105.
} 
It is in this situation that the call for "empowerment" presents itself as if it were a compensatory symptom. Hence, in spite of my skepticism concerning the story that I suspect insiders to suspect me to have told, I think it is possible to see the Union shift from emancipation to empowerment so long as this movement is not understood as going beyond one and into the other (in the sense of "absorption"), but rather as evidence of how the absence of the first gives rise to the second-to the effect that the second becomes a symptom of the absence of the first.

\section{Why emancipation? - Historical consciousness}

But why should the question of emancipation be important, let alone be the right question to ask? Why would one harbor the respective expectation towards the Union? Isn't it enough that the Union has until recently increased the size of the pie? And hasn't it-remember the truism-been successful at securing peace? Why expect something else, something entirely different?

The Union is an inherently immodest organization. It has successfully taken the place of Europe. Throughout its modern history, however, Europe has looked at itself from a historical perspective. Regardless of whether one has perceived progress or decay, what has mattered was locating the current age within a continuum (to which "post-history", of course, belongs as an element). Until to this day, Europe's premier mode of practical reasoning is not analytic moral philosophy, but historical triangulation. ${ }^{19}$

19 See Wilhelm Schmidt-Biggemann, Geschichte als absoluter Begriff: Der Lauf der neueren deutschen Philosophie (Frankfurt aM: Suhrkamp, 1991). 
Over the course of the nineteenth century, emancipation took a prominent place when it came to assessing the trajectory of societies. ${ }^{20}$ It became, borrowing Koselleck's expression, a concept signifying a historical movement (geschichtlicher Bewegungsbegriff). ${ }^{21}$ This concept signifies either the moment of liberation or a process of gradual progress. It can be linked either to certain groups or to humanity at large. Broadly understood, it is supposed to represent something that is already under way. Thus understood, emancipation can be halted or inhibited. But it cannot be eliminated. It is the force of history itself.

Arguably, modern liberal democracy is the outgrowth of a movement of emancipation. To present itself in this light, at any rate, is part of its legacy. At the same time, liberal democracy is the attempt to bring the project of emancipation to its legal completion. All are equal. All have rights against whoever exercises lawful authority over them. ${ }^{22}$ Any further step of emancipation would have to move beyond eliminating the whim of unconstrained power and to wrestle with the mutual dependencies in which humans trap themselves because of their mode of co-operation. This, at any rate, was the idea at the heart of Marx's idea of "human emancipation".

By taking up the theme of emancipation I do not mean to suggest the survival of what has been claimed to be, in the nineteenth century, the driving force of history. Nowadays, European humanity appears to be plagued with fatigue and disposed to follow its American sibling on the twin path towards relentless discipline and perpetual infancy. Nevertheless, the theme of emancipation is present in the eschata of human history that the Union has embraced after the demise of really existing socialism, namely democracy,

\footnotetext{
${ }^{20}$ See Grass \& Koselleck, note 1 at 169, 176.

${ }^{21}$ See Reinhart Koselleck, Vergangene Zukunft: Zur Semantik geschichtlicher Zeiten (Frankfurt aM: Suhrkamp, 1979) at 341.

22 The only conceivable further form of emancipation would eliminate the status difference between citizens and non-citizens. Whether this would also be desirable is a different matter.
} 
human rights and the rule of law. They comprise the core elements of the legacy of legal emancipation. What is more, the Union appears to be the resolved riddle of human history because these values appear to have been proven "right" in the face of the experienced futility of attempts to move beyond them. While it may be possible to fancy a more emancipatory alternative to liberal democracy it is more than doubtful that attempts at its realization would not invariably relapse into some kind of barbarism.

Nevertheless, any practical belief that is nurtured by the conservative fear of more risky alternatives ${ }^{23}$ must come with a sense of loss. The one author who quite perceptively pinpointed this loss right at the moment at which liberal democracy appeared to have emerged victorious from "world history" realized that what we experienced was not a feast of emancipation but the shrinking of human ambition to leading an obedient life of production and consumption. The liberal society of the end of history systematically belittles humans in that it no longer accords them a role in the making of history. The resulting awareness that one is less than one could be induces in some an unhappiness with a state in which everyone is supposed to be happy in the sense described by British moral philosophers (e.g., experience "pleasure" or enjoy the satisfaction of "preferences"). As Fukuyama observes:24

[T] he dissatisfaction arises precisely where democracy has triumphed completely: it is a dissatisfaction with liberty and equality. Thus those who remain dissatisfied will always have the potential to restart history.

The post-1989 world of liberal democracy needs to be heeded of its propensity to produce a desire in humans to pursue the cause of emancipation beyond its limit. This desire, Fukuyama tells us, is dangerous. The boulder of liberal freedom would merely have to be rolled up the hill after those who were

${ }^{23}$ See Albert Hirschman, The Rhetoric of Reaction: Perversity, Futility, Jeopardy (Cambridge, Mass.: Harvard University Press, 1991).

${ }^{24}$ Francis Fukuyama, The End of History and the Last Man (New York: Basic Books, 1992) at 334. 
annoyed by seeing it sit on the top had pushed it down. At its end, history changes its shape from a linear progression to the cyclical recurrence of the same. What is more, history morphs from the meaningful realization of an ideal into the senseless struggle for and against the same. Against this backdrop, the European Union appears cast in the role of Schmitt's katechon, ${ }^{25}$ that is, an empire entrusted with averting apocalypse, in this case, by keeping those unruly drives for social emancipation at bay that are prone to lead in one way or another to authoritarian disaster.

\section{Why emancipation? - The genus of all deficits}

The role of emancipation as a historically self-adopted European measure of history is not the only reason for reintroducing the topic. The other reason concerns the variety of deficits that the Union has managed to accumulate. The European Union is burdened-albeit not all agree-with a democracy deficit, a social deficit and perhaps also with a justice deficit. Once these are put into perspective, we may realize that emancipation is the genus of which democracy, solidarity and social justice are a species. A disconnect between European institutions and the peoples of Europe affects the reality of political freedom. European peoples are confronted with serious obstacles when it comes to ridding themselves of rules or practices that they dislike. A democracy deficit is, thus understood, another name for diminishing opportunities to exercise political freedom effectively. If that is the case then there is definitely no emancipation. Similarly, when the Union fails to come to the rescue of people who are unable to help themselves these people end up being locked in their social station. This is not per se indicative of the creation

25 See Carl Schmitt, The Nomos of the Earth in the International Law of the Jus Publicum Europaeum (trans. G. L. Ulmen, New York: Telos Press, 2006) at 59-60. The task of the Christian empire was to restrain the coming of the Antichrist. 
of greater freedom. ${ }^{26}$ From such a social perspective, it appears that the core reason why the Union is not an agent of emancipation is that it does not emancipate humans from the stresses and strains of a highly competitive economy.

But one needs to be circumspect at this point. Since they began slowly to rise to the level of the default law of social existence in the eighteenth century, competitive markets have been associated with a mode of emancipation from markets that is compatible with them. Self-made men like Benjamin Franklin first epitomized this mode. His economic success enabled him to extricate himself from the unpredictable world of transactions and to lead the culturally inherited life of a gentleman. ${ }^{27}$ Success on markets promised decommodification as its reward. However, this was a culturally backwardslooking manner of conceiving of market-facilitated emancipation. More consistent with competitive markets is the vision of market success that is immanent and allows one to dominate and to lead certain sectors. ${ }^{28}$ While this entrepreneurial form of emancipation is less complete than freedom that is owed to the amassing of wealth it is nonetheless a mode of rising above members of the crowd that have to busy themselves with adaptation to shifting demand. ${ }^{29}$ In both the case of the genteel rentier and of the entrepreneur markets facilitate the emancipation from markets. They do not, that is, presuppose shifting from private to public liberty.

\footnotetext{
26 If these examples do not sound convincing then consider the sense of alienation that citizens feel towards the Union and which has been recognized in various of its official documents. It has not disappeared in spite of all efforts at "selling" the Union to its citizens by making it more accessible and transparent.

27 See Gordon S. Wood, The Radicalism of the American Revolution (New York: Vintage Books, 1991) at 85.

28 This form of emancipation is epitomized by Schumpeter's entrepreneur. See Joseph A. Schumpeter, Capitalism, Socialism and Democracy (reprint, London: Routledge, 1994) at 132-133. ${ }^{29}$ I once could not help to overhear a conversation between a young entrepreneur in the construction business and one of his friends in which the former expressed confidence that he would stop working at the age of thiry. I have never found out whether he succeeded at that.
} 
The question is whether such a recalcitrant persistence of the private is the key to understanding the remarkable career of empowerment. If it were then it would not be based on a "political" emancipation, which promises to offer reprieve from the bleak realities of economic life through the ennobling exercise of active citizenship; however, it would also not be part of "human" emancipation, which, according to Marx, establishes common control over economic dealings. Rather, empowerment would represent nothing short of the economic absorption of the idea of emancipation itself.

It remains to be seen how such a partial idea of being lucky enough to rise above the market can be semantically presented in universal form. The key thereto may well be the commitment to put the "individual" at the heart of the Union's concern.

Below I will briefly sketch Marx's distinction between mere political and human emancipation. The latter is, arguably, Europe's greatest and also most tragic political idea, for it will be forever tarnished with the memories of "really existing socialism". With this sobering experience in mind I go on to examine whether market liberalism scores higher on the score of emancipation. Arguably, it might do so only if it is "socially embedded" by virtue of various strategies of de-commodification. Interestingly, however, the Union does not seem to endorse such a view. The Union appears to be wedded to the market's immanent absorption of emancipation in the guise of "entrepreneurship" and "empowerment". 


\section{Political and human emancipation}

The idea of a "human", as opposed to a mere "political", emancipation appears in the early works of Karl Marx. ${ }^{30}$ He introduced this distinction in his notorious essay on the Jewish question ${ }^{31}$ and used it in his polemic against the young Hegelians. ${ }^{32}$

As a concept, "political" emancipation refers to different, however related, phenomena.

First, the world of the bourgeoisie, in which human beings appear as hommes-i.e. by nature as isolated individuals, ${ }^{33}$-emancipates market dealings from the constraints defined by political relationships between and among estates, religious communities or guilds. ${ }^{34}$ Once "emancipated", the economy emerges as governed by principles and regularities of its own. Even though of human origin, these are not of human design. For example, that one must lower the price of a good in order to sell larger quantities has not been laid down as a rule by some regulator. It reflects a regularity that is either of an empirical nature or an inference drawn from the premises of rational behavior. Even though humans are involved in their making, the principles and rules of economics are not an extension of their plans and intentions. Hence, they appear to humans as "essentially" different from them. As Marx would note in German Ideology and the Grundrisse, the collision among

\footnotetext{
${ }^{30}$ For a valuable introduction, see Wolfdietrich Schmied-Kowarzik, 'Karl Marx als Philosoph der menschlichen Emanzipation: Rehabilitation eines verkannten Denkers' In G. Petrovic \& W. Schmied-Kowarzik (eds.), Die gegenwärtige Bedeutung des Marxschen Denkens: Marx-Symposium 1983 in Dubrovnik (Bochum: Bouvier, 1983).

31 See Karl Marx, ,Zur Judenfrage' In Marx-Engels Studienausgabe, vol. 1 (ed. Iring Fetscher, Frankfurt aM: Fischer, 1966) 31-60. On Marx's embarrassing anti-Semitism and his defence of the emancipation of Jews, see Shlomo Avineri, 'Marx and Jewish Emancipation' (1964) 25 Journal of the History of Ideas 445-450.

32 See Karl Marx \& Friedrich Engels, Werke, vol 2 (ed. Institut für Marxismus-Leninismus beim ZK der SED, Berlin: Dietz Verlag, 1976) at 117-128.

33 See Marx, note 31 at 51-52.

34 See ibid. at 51-52.
} 
individuals pursuing their own good in the economic sphere gives rise to an "alien social power". Their relations of interdependence are reflected back to them as an "autonomous process and force". The social relationships among individuals thus are imagined to be governed by something that is beyond their control. ${ }^{35}$ In the case of "fetishism", effects that are caused by human relationships are even attributed to things. This matter is manifest in the belief, for example, that commodities possess "inherent" value and therefore attain value in exchanges. ${ }^{36}$

Second, the emancipation of the economy from politics is accompanied by the mere political emancipation of human beings from the economy. For example, the emancipation from an established religion through the introduction of a constitutional principle of neutrality among churches and denominations only eliminates religion from the purview of state activity but leaves it in place in civil society. Similarly, the elimination of all property qualifications for the exercise of the franchise, while neutralizing economic inequality at the ballot box, leaves private property in place where it matters the most. Political emancipation constitutes a realm that is different from the economy. People appear through the formidable ethical lens of citizenship (indeed, they are cast in the capacity as a "species-being"). The state, qua embodiment of this realm, is elevated above religion and private property. Taking the perspective of the state, human beings partake of this emancipation from religion and property. Yet, the political form of emancipation from property and religion does not extend to the world of ordinary practice in the economy and civil society. Political emancipation is human emancipation in imagined form. It involves a split into the idealized realm where human beings appear as citoyen and the real world of the bourgeoisie where they compete as hommes

\footnotetext{
35 See Karl Marx, Grundrisse der Kritik der politischen Ökonomie, Werke, note 35, vol. 42 at 127; idem \& Friedrich Engels, Die Deutsche Ideologie, Werke, note 35, vol. 3 at 34.

36 See Jon Elster, An Introduction to Karl Marx (Cambridge: Cambridge University Press, 1986) at 57.
} 
for their personal gain. From this follows, that a dominant religion or the unequal effects of private property stay in place as long as they are not brought about directly by the state. This explains how the two meanings of political emancipation hang together. Anything that would be an injustice if committed by the state may legitimately be brought about on the basis of private dealings taking their course. While the political sphere is formally cleansed of traditional markers of social distinction, the emancipated economy is free to reintroduce them through the back door.

The political system of the bourgeoisie has torn down the walls of status inequality. ${ }^{37}$ It has constituted human beings as individuals who are no longer formally distinguished from one another. At the same time, these same individuals are pit against one another in competitive races for subsistence and profit. The society of the bourgeoisie thereby creates a synthesis of political society and slavery. Everyone is included as an equal both into the political body and into the uncontainable economic system whose fatal nature is particularly sharply revealed in times of trade or fiscal crisis. Subordination to economic pressures predominates this "synthesis" since the modern economy is governed by laws and regularities whose force politics is de facto not free to ignore. ${ }^{38}$ Indeed, so long as the fundamental rights of the bourgeoisie are protected by political society, there is no hope that humans could ever emancipate themselves from self-created necessities. In the words of Wood: 39

What is alienating is [...] that under capitalism human beings cannot be the masters, whether individually or collectively, of their own fate, even within the sphere where that fate is a product solely of human action.

\footnotetext{
${ }^{37}$ See Marx \& Engels, note 32 at at 123.

38 See Iring Fetscher, Karl Marx und der Marxismus: Von der Ökonomiekritik zur Weltanschauung (4th ed. Munich: Piper, 1985) at 60.

${ }^{39}$ Allen W. Wood, Karl Marx (2d. ed. London: Routledge, 2004) at 49.
} 
By contrast, human emancipation would establish joint control over the quasinatural objective relationships created by the antagonistic co-operation within the economic sphere. Indeed, in an ideal society everyone would be doing his or her bit at various stations in the division of labor on the basis of insight into what is in the interest of all. ${ }^{40}$ Its realization presupposes, evidently, a full reconciliation of the political and the private sides of our social existence.

Socialism represents, if anything, the project of overcoming or channeling competition by means of exercising, in one way or another, joint control over production and distribution. Several reasons can be invoked in favor of socialism. The reason that Marx tried to elicit from his analysis of capital was that owing to capitalism's propensity to crises an association of producers would arrange for a more effective and less wasteful way of producing goods and satisfying needs. ${ }^{41}$ But it is conceivable to support socialism for different reasons, for example, on the ground that a socialist society would have power to curb social inequality and put an end to the absurdity with which an advanced market economy generates hitherto unknown "needs". ${ }^{42}$ There is one perspective on socialism, however, that is most congenial to the libertarian strand of capitalism. From this perspective, the emancipatory appeal of socialism resides in its potential to replace a system of man-made necessity with the joint political control over a common life. ${ }^{43}$ Socialism would mark humanity's exodus from the disempowering effect of second nature towards a world of collective self-government.

Marx's idea of human emancipation is the perhaps greatest idea of the modern world for the simple reason that it consistently elaborates the ideal of

\footnotetext{
40 See Deutsche Ideologie, note 35 at 33.

${ }^{41}$ See merely, James A. Caporaso \& David P. Levine, Theories of Political Economy (Cambridge: Cambridge University Press, 1992) at 70-72.

42 See Erich Fromm, To Have or to Be? (New York: Harper and Row, 1976) at 163-164.

43 For a fine reconstruction of this point, see Wood, note 39 at 49-50. As is well known, the presentation of socialism in terms of freedom enraged Friedrich August von Hayek. See his The Road to Serfdom (London: Routledge, 1991; first edition 1944) at 19-20.
} 
freedom, extending it to the control of the circumstances that emerge as the unintended consequence of human practice. In its significance it is comparable to what Plato's republic stands for in the context of ancient philosophy. It is comparable, I hasten to add, to this formidable work also owing to the problematic feature that they share. Both raise the questions whether the envisaged unity of social co-operation can be realized only at the cost of most serious oppression. Really existing socialism has taught a quite disheartening lesson. Communism, at any rate, no longer looks attractive after Stalin, Ceaușescu or Honecker have left their mark on a formerly noble aspiration (not to mention Pol Pot or Kim Il-sung).

\section{The dilemma}

It needs to be recognized, however, that the inclination towards authoritarianism is not an accidental feature of human emancipation. It is not only the case that due to some contingent circumstances of human action and human imperfection the realisation of the ideal cannot live up to the ideal itself ("Theory is Marx, practice a mess" - "Die Theorie ist Marx, die Praxis ist Murks"). The realization of human emancipation reveals a deeper predicament. The full realization of freedom as imagined by moderns, manifest in individual freedom of choice and of expression, presupposes freedom as understood by the ancients, who prefer collective selfdetermination even where it rides roughshod over what liberals believe to be individual rights. ${ }^{44}$ Apparently, the totality of human freedom is at war with itself. It suffers, borrowing Hirschman's felicitous phrase, from a propensity to self-subversion.

${ }^{44}$ On this contrast, see Constant, note 11 at 311-312. 
Revolutionary socialists understood that the "leap" towards the realm of freedom could not be made by waiting, as Karl Kautsky suggested, until the historical development of capitalism would reach the point at which it would invariably and automatically transform itself into a system of common political control of production and distribution. Lukács, for example, believed that capitalism, if it failed to somehow perpetuate itself, would lead to outright desolation and destruction. ${ }^{45}$ But the inevitable revolutionary action could also not rely on the actual proletariat or other groups of society whose minds were poisoned with the false consciousness that the capitalist society creates in its subjects. ${ }^{46}$ The intentions of the working class, even though unconsciously aiming at the right thing, are tarnished by a lack of selftranscendence that the proletariat has to enact as the last class of human history. ${ }^{47}$ It must not merely pursue its own interest, but the interest of humankind. In Lukács view, it would therefore have also been a vain hope to expect, as Rosa Luxemburg $\mathrm{did}^{48}$ that the revolution would be precipitated "organically" by the local resistance merging into one large socialist movement supported by the working class and other disadvantaged groups. ${ }^{49}$ According to Lukács, the proletarian revolution, unlike other revolutions in human history, would have remained impossible had it not used the soviets qua "proletarian state". This state would be the instrument of a vanguard party whose acts are to be based upon the objectively possible classconsciousness of the proletariat. ${ }^{50}$

The quest for human emancipation is therefore burdened with the "organizational question" (Organisationsfrage). It addresses the perplexing fact

\footnotetext{
${ }^{45}$ See Georg Lukács, Geschichte und Klassenbewusstsein: Studien über marxistische Dialektik (10th ed., Neuwied: Luchterhand, 1988) at 436, 477-479.

${ }^{46}$ See ibid. at 124, 126.

47 See ibid. at 157.

${ }^{48}$ See Rosa Luxemburg, Schriften zur Theorie der Spontaneität (ed. S. Hillmann, Reinbek: Rowohlt, 1970) at 158-159.

${ }^{49}$ See Lukács, note 45 at 439-440, 447.

50 See ibid. at $128,152-153,434-435$,
} 
that a movement that is deeply committed to the equal freedom of all has to embrace the submission of those on whose behalf emancipation is to be effected. The vanguard party is the resolution of a prisoner's dilemma constituted by the false consciousness concerning the right aspirations and by a false confidence in an "organic" transition towards socialism. Lukács was perhaps the most articulate defender of this idea. In the face of the danger of "opportunist" backsliding by social democrats, the party would serve as the trailblazer of emancipation, fully aware of the fact that revolutionary class consciousness was not an empirical matter but a perspective which to adopt was right on the ground of insight into the development of history. ${ }^{51}$

Resolving the organizational question presupposes, however, agents that possess an intuitive understanding. ${ }^{52}$ They have to have a grasp of the present and future totality in order to arrive at the particulars and to determine how everything fits into a larger whole. This type of intellect would not only be able to arrive at the objective consciousness of the new class and to discern it from the false consciousness of the bourgeoisie and the masses; it would also be capable of anticipating what the needs and interests of human beings would be once the masses had made the transition. The vanguardness of the vanguard party consists precisely in its ability to anticipate what the good life would be for the people whom it is supposed to emancipate and who, after emancipation, would freely endorse what they may not have endorsed before. ${ }^{53}$ In its actions it bears semblance to a doctor who inflicts pain on her patients because the pain is necessary to overcome the condition under which pain is felt in the first place.

\footnotetext{
51 See ibid. at 128.

52 On the notion of the "intuitive understanding", see Eckart Förster, The Twenty-Five Years of Philosophy (trans. B. Bowman, Cambridge, Mass.: Harvard University Press, 2012) at 144, 148.

${ }^{53}$ Ironically, Hayek's rant against submission to the discretionary power of planners did not even confront the fact that the vanguard party had to claim to act in interests that necessarily had to be unbeknownst to the subjects of emancipation. See Hayek, note 43 at 48-50, 69
} 
Resolving the organizational question presupposes also according precedence to ancient over modern liberty. This concerns, in particular, the participants in the vanguard project. The party needs to be governed by strong camaraderie and cannot have time for long-winding discussions or open opposition to its leadership. ${ }^{54}$ The conscious decision in favor of the realm of freedom implicates a waiver of individual liberty in the bourgeois sense. A new type of freedom would be reconciled with solidarity. The synthesis of freedom and solidarity is "discipline". ${ }^{55}$ Moreover, participation in the vanguard presupposes a total devotion to the cause that is reminiscent of Rousseau's aliénation totale. Being part of the vanguard implies the "Aufgehen der Gesamtpersönlichkeit"56 in the practice of the movement. The merging with the movement prefigures the freedom that is attained as a consequence of human emancipation. It transcends the distinction between rights and obligations. Rights would be understood to be means for doing the right thing.

According to Lukács, the "dialectical" process of the development of the working class as a whole depends on the organizational separateness of the "conscious" vanguard from the merely unconsciously revolutionary masses. ${ }^{57}$ Undoubtedly, the masses that are not part of the vanguard party will experience the rule by the party exactly in the manner in which Constant described the effect of ancient liberty on people who want to be free in the modern sense, namely as tyranny. ${ }^{58}$ Indeed, Lukács emphasizes that, in its revolutionary role, ${ }^{59}$ freedom cannot be an end in itself, but has to serve the dictatorship of the proletariat as an entirely sovereign form ${ }^{60}$ of rule. ${ }^{61}$ The

\footnotetext{
54 See Lukács, note 45 at 445.

55 See ibid. at 480-481.

56 Ibid at 486.

57 See ibid. at 512.

58 See Constant, note 11 at $310,318$.

${ }^{59}$ See Lukács, note 45 at 447.

60 The sovereignty of this dictatorship is also manifest in the fact that the vanguard party constitutes itself on the basis of its own free choice. See ibid. at 499-500.
} 
vanguard party must have the flexibility, acumen and room for maneuver to adapt its policies and strategies to the exigencies of the situation. ${ }^{62}$ Hence, the class-unconscious masses will experience the rule of the party as terror and despotism for they can at any time be "interrogated, dismissed, condemned, beggared, exiled or sentenced to death by [their] magistrates and superiors." 63 They end up necessarily alienated from the polity because the one reason does not apply to them that the ancients had for accepting the tough love of ancient liberty, namely the "compensatory" experience of being personally important to the polity and to take an active role in its life. ${ }^{64}$ The masses enjoy neither modern nor ancient liberty.

It is important to note which conclusions do not follow from this analysis. First, insight into the predicament of human emancipation, which replicates the conflict between ancient and modern liberty, does not solve the problem that emancipation was designed to solve. In other words, in the face of its failure, the need for emancipation persists even if the most straightforward way to attain it is irreconcilable with the type of beings we take ourselves to be. Second, Constant senses that while ancient liberty was unfit for modern individuals it was conceivable to imagine a form of political liberty that is right for them, namely, representative democracy. ${ }^{65}$ It cannot be ruled out yet that an equivalent substitute can be found for human emancipation.

So far we have only examined the first horn of the dilemma. Embracing human emancipation directly is likely leading to tyranny. The freedom-

\footnotetext{
${ }^{61}$ See Carl Schmitt, Die Diktatur: Von den Anfängen des modernen Souveränitätsgedankens bis zum proletarischen Klassenkampf (reprint, Berlin: Duncker \& Humblot, 1978) at 145-146. See, for example, on freedom of the press as a tool of socialist progress, Vladimir Illitch Lenin, 'Die nächsten Aufgaben der Sovietmacht' In Für und wider die Bürokratie: Schriften und Briefe 19171923 (Reinbek: Rohwolt, 1970) at 42.

${ }^{62}$ See Lukács, note 45 at 450 . This did not escape Hayek's attention. See note Hayek, note 43 at 48-49.

${ }^{63}$ Constant, note 11 at 312 .

64 See ibid. at 316, 320.

65 See ibid. 325-327.
} 
denying effects of a market economy, however, do not disappear simply because the remedy is also freedom-denying. The problem does not go away simply because one or another solution does not work. At the same time, we have conceded to Marx that the politically emancipated economy constitutes a threat to freedom. In light of the dubious value of the remedy it cannot be wrong to reconsider what one has to believe in order to consider capitalism a threat to freedom. The focus needs to shift, therefore, to the second horn. It pays to re-examine capitalism sine ira et studio before we return to the question if and how the European Union fits into the story of human emancipation.

\section{Capitalism: The value of choice}

One of the cardinal principles of the European economy-and of the capitalist system in general-is competition. In the case of the Union, the commitment to competition has been particularly strongly pronounced during the pursuit of the so-called "Lisbon Strategy. It was supposed to raise the Union to the level of the most competitive and dynamic knowledge-based economy of the world. ${ }^{66}$ But even aside from this effort, which has been superseded by the more muted "Europe 2020 Strategy", competition has always been embraced by the Union because of its supposedly overall beneficial effects. Competition is believed to foster economic growth and to benefit the consumer. ${ }^{67}$

Competitiveness is an essential ingredient of the capitalist system and a consequence of the decentralized mode of resource allocation. ${ }^{68}$ The epitome of decentralization is the right to private property. It signals that private

\footnotetext{
${ }^{66}$ See, Presidency Conclusions, 24 March 2000.

${ }^{67}$ This, at any rate, it the normative principle invoked by neoclassical economic philosophy. See Robert Bork, The Antitrust Paradox: A Policy at War With Itself (2d. ed. New York: Free Press, 1993) at 81.

${ }^{68}$ See Hayek, note 43 at 27-30.
} 
actors, rather than more or less centralized political bodies, decide on matters such as investment, consumption or saving. If allocative decisions are decentralized everyone needs to be heeded of the decisions of others.

The basic paradox of capitalism consists in the fact that while its decentralized mode of production and distribution operates on the basis of free choice it gives also rise to a life governed by necessity. ${ }^{69}$ The term "necessity" denotes both the context and the quality of demands. They arise from the life process and command our attention with the unwelcome urgency characteristic of physical drives. ${ }^{70}$ Admittedly, the latter is only true if human beings are indeed hungry in anticipation of future hunger; ${ }^{71}$ but economic rationality is indeed the means to represent temporally remote urgency today. Prudence can be quite dictatorial. Responsible parents, for example, invest time and money in the human capital of their children. Otherwise their offspring would scarcely be able to live and prosper in a competitive world. Children have to be molded into "ability-machines". ${ }^{72}$ In anticipation of the necessities that they will have to respond to they need to possess a variety of marketable skills. It is imperative, therefore, to send them to math camp or even to a school in a foreign country. This is all the more so as one has to reckon that others are going to do the same. A competitive life is a life spent on engaging in pre-emptive strikes. The requisite functional necessities originate from "the hard discipline of the market" ${ }^{73}$

Since, under competitive conditions, people are not in control of their options, their skills and plans had better be adjustable to various alternatives.

\footnotetext{
${ }^{69}$ See Karl Marx \& Friedrich Engels, Die Deutsche Ideologie, MEW vol 3. (Berlin: Dietz, 1978) at 76.

70 See Hannah Arendt, The Human Condition (Chicago: University of Chicago Press, 1958) 71-73.

${ }^{71}$ See Thomas Hobbes, De Homine 10/3.

${ }^{72}$ See Michel Foucault, The Birth of Biopolitics: Lectures at the College de France 1978-79 (trans. G. Burchell, Houndmills: Palgrave, 2008) at 229.

73 Friedrich August von Hayek, 'Individualism: True and False' In Individualism and Economic Order (Chicago: University of Chicago Press, 1948) 1-32 at 24.
} 
Evidently, given the vagaries of markets, life cannot be lived pursuant to one existential project or according to an individual "plan". It is subject to the incessant recurrence of smart choices between and among non-chosen options. ${ }^{74}$ Advocates of a free society ${ }^{75}$ do not see a problem in this. What matters to them is that as long as one is not coerced into doing or forbearing something one is free regardless of whether one finds the options unattractive. ${ }^{76}$

This is, however, counterintuitive. Someone who does not find his preferred Leberknödelsuppe on the menu may be still given a choice between a hamburger and stew. Alas, for someone who would rather eat Leberknödelsuppe, but is not free to have one, the choice between a hamburger and stew is of no value. This is a basic problem that the advocates of a free society ignore. They do so, perhaps, for the simple reason that in their view the value of choices resides in choosing itself. After all, choosing is preceded by some exercise of human rationality. This may be the value that advocates of a free society truly endorse. It may explain why we have reason to believe that in their view there can never be a choice without value. Is it not better to have a choice between hamburger or stew than being forced into eating one or the other? The difference is of moral significance. Hence, freedom appears to be preserved so long as people are given some choice. ${ }^{77}$ So long as workers can choose between a physically or a sexually abusive employer they are better off than they would be if they were forced into working for either. ${ }^{78}$ The explanation is that in making a choice they are free to take their relative

\footnotetext{
74 See Ulrich Bröckling, Das unternehmerische Selbst: Soziologie einer Subjektivierungsform (Frankfurt aM: Suhrkamp, 2007) at 88, 106.

75 Since irony is no longer noticed I emphasize that "advocates of a free society" signifies believers in laissez fair capitalism, such as Milton Friedman.

76 This is clearly revealed in Milton Friedman, Capitalism and Freedom (2d. ed., Chicago: University of Chicago Press, 1982) at 14-15; see also Hayek, note 73 at 24.

77 See Hayek, note 73 at 16, 24.

${ }^{78}$ See, ibid., at 15. This is not Hayek's example!
} 
disutility into account. ${ }^{79}$ One must wonder, hence, whether the hullabaloo about interrogation methods, such as waterboarding, would subside if the subjects were given a choice between immersion into water or the administration of electric shocks. We shall return to this point below.

Be that as it may, it is nonetheless true that a market economy can dramatically reduce the range of options if one focuses not on recurring singular choices but on various ways of leading a whole life over time. Indeed, reasoning as a clever market participant does not involve reasoning about life but rather the recurrent choices that are mostly informed by the calculation of marginal utility. If anything at all lends coherence to life then it is the formal maxim of maximization.

\section{Politics and the rule of the few}

Assume that a substantial number of the working members of society wish to allocate an equal amount of their daily time to working and to spending time with their family. Imagine that they live in a community where a smaller number of people busy themselves with leading excessively productive lives. In a competitive business environment it is to be expected that the incidence of this smaller number will raise the bar of achievement for everyone. Consequently, a substantially larger number of people will see themselves

\footnotetext{
${ }^{79}$ I add, in passing, that this was one of the reasons why the American realist legal theorist Robert Hale believed that all market exchanges are coerced exchanges. Ordinarily, a situation of coercion does not involve the physical incapacity to do otherwise on the part of the coerced subject, but rather leaves this subject with a choice between unpalatable alternatives. A robber leaves one with the choice to hand over one's purse or to be killed. Similarly, an employer leaves the unemployed with a choice to starve or to work for a pittance. On Hale's view, see the illuminating discussion by Barbara H. Fried, The Progressive Assault on Laissez Faire: Robert Hale and the First Law and Economics Movement (Cambridge, Mass.: Harvard University Press, 1988) at $49-50$.
} 
confronted with the necessity of having to alter their time allocation in order to make a living. They are de facto less free to spend time with their family.

This freedom-denying consequence of competition did not escape the attention of Hayek. Almost gleefully, he exposed the inequities of a market economy, but only in order to dismiss them as irrelevant: ${ }^{80}$

Competition is, after all, always a process in which a smaller number makes it necessary for larger numbers to do what they do not like, be it to work harder, to change habits, or to devote a degree of attention, continuous application, or regularity to their work which without competition would not be needed.

Of course, the substantial number of people, by virtue of being the democratic majority, may want to decide to introduce a rule that limits the amount of time that may be spent on productive pursuits, for example, by limiting the regular working time. The smaller group would likely claim, aided and abetted by the advocates of a free society, ${ }^{81}$ that such a rule constitutes an offence to individual liberty. But, remarkably enough, the rule adopted by the majority is not only perfectly legitimate from a democratic point of view; it is also apt to restore the liberty of the majority that they have lost because they had to adapt to a situation created by a few. Hence, what advocates of a free society really demand is that the majority yield to the minority that puts their liberty to a productive use. These advocates are, if anything, not neutral between and among various human forms of enjoying liberty. Hayek has always been quite outspoken about this: ${ }^{22}$

[T] he merit of competition is precisely that it gives the minority a chance to prevail. Where it can do so without any coercive powers, it ought always to have the right.

\footnotetext{
80 Friedrich August von Hayek, Law, Legislation and Liberty vol. 3: The Political Order of a Free People (2d. ed., London: Routledge, 1982) at 77. I hasten to add that the ostensible immoralism of Hayek's theory is actually a mitigating factor.

${ }^{81}$ See Friedman, note 76 at 8, 11 .

${ }^{82}$ Note 138 at 30.
} 
Translated into political terms this means that the few indirectly rule over the many. Competition creates a trajectory for social oligarchy.

\section{Nobody's responsibility}

Advocates of a free society will point out that there is a difference between those constraints on liberty that are imposed by political institutions and others that arise as mere side-effects of the general exercise of liberty. ${ }^{83}$ It is one thing to prohibit the sale of Aperol, but quite another if Aperol is not supplied in stores owing to inexistent consumer demand. Whereas the former may well be objectionable, the latter is not.

The force of this reply can be drawn out in at least two different ways.

Adopting a rule against competitive behavior is a political choice. A choice of this type is always contested, not least because it is likely to implicate private autonomy. By contrast, if matters are left to the market, constraints emerge as an aggregate effect of individual acts that are not intended as restrictions. ${ }^{84}$ If Aperol is not in supply because virtually nobody cares about the product then the person constrained from buying it has nobody to blame. Who is responsible for the overall composition of consumer preferences? Nobody. Since consumers at large have decided not to buy a product, owners of shops have not ordered it. None of them, however, intended to bring about a situation in which Aperol is generally unavailable on the market. Neither individuals nor a collective body have made this choice. Nobody interfered with the interest of the consumer. Nobody bears any responsibility. This is the way of the world.

\footnotetext{
${ }^{83}$ See, in this vein, Friedman, note 76 at 11.

84 See Hayek, note 43 at 15, 70, where Hayek points out that prices are not determined by a "conscious will".
} 
Even though this elaboration of the reply is not terribly sophisticated, it nevertheless explains the appeal that market solutions have to those who are averse to being burdened with demands made by others. Markets are a way of disposing of responsibility. If things go wrong because of markets then there is a strong prima facie case that there is nobody to blame. Markets are not agents. ${ }^{85}$ They are media for the co-ordination of individual conduct. Therefore, market solutions depoliticize. They create side-constraints on everybody for whose existence nobody can be held to account. ${ }^{86}$ Likewise, any adverse situation that people may find themselves in is more easily borne by them if this situation is not the direct result of allocative decisions. Inequality is more readily accepted if it stems from the impersonal forces that reflect the competitive efforts of many. ${ }^{87}$

This reply is still incomplete. It does not address the question why a community that would be capable of adopting rules would still choose to abstain from adopting collective choices and let markets run their course. The justification for such an abstention may be manifold and may draw, for example, on the wealth-generating effects of the "spontaneous" orderings that emerge from free exchanges. ${ }^{88}$ True advocates of a free society, however, would have to point out why and how such an abstention is consistent with

\footnotetext{
${ }^{85}$ See Friedrich August von Hayek, Law, Legislation and Liberty, vol. 2: The Mirage of Social Justice (2d. ed. London: Routledge, 1993) at 70, where Hayek explains that the "impersonal process of the market" can be neither just nor unjust "because the results are not intended or forseen, and depend on a multitude of circumstances not known in their totality to anybody". See also Hayek, note 43 at 15, 57, who is, however, guilty of conflating impartiality with indifference. The market operates with indifference as regards the needs of particular individuals, but this does not mean that the distribution is impartial with regard to the "usefulness" (to use Hayek's term) of products in the eyes of those who can afford them. The market very partially rewards those who are able to motivate others to pay for what they do. That Hayek mistakes impartiality for indifference is also evident from his remark that one is impartial if one does not have an answer to a certain question.

86 This is not to say that the advocates of a free society would not see a role for political choices when it comes to unintended collective consequences that threaten to subvert the smooth functioning of market transactions. Hence, a free society can well be described as a "risk society", that is, a society that needs to assess and manage the collective risks to which its existence gives rise. See, generally, See Ulrich Beck, World at Risk (trans. Ciaran Cronin, Cambridge: Polity, 2009). ${ }^{87}$ See Hayek, note 43 at 79-80.

88 See Hayek, note 85 at 114-115.
} 
liberty. Hence, a somewhat better elaboration of the reply would emphasize, at the outset, that any individual action always takes place in the face of circumstances beyond the agent's control. Nobody is ever unconstrained. The question is, therefore, which type of constraint is more consistent with liberty, that is, constraints that originate either from political choices or from aggregate market effects.

The advocates of a free society will likely point out that political choices directly subordinate the will of one human being to the will of another. It is in this vein that they will also reply to the hypothetical in which an individual is confronted with a choice between water-boarding and electro shocks. Even though there is a choice, it is still a choice between two different coercive acts. Both options imply the subordination of one human being to another. Options that arise from the "impersonal" operation of the market, by contrast, do not carry the implication of subordination. Rather, they are the outcome of a competitive process that is as "blindfolded" as justice due to its "impersonal" nature. ${ }^{89}$ Consequently, if someone were, for want of resources, confronted with either having to suffer starvation or selling a kidney on the market for organ transplants, this would be the person's free choice since neither of the options involves an act of external coercion. It follows that advocates of a free society actually accept the claim that the value of having a choice is also a function of the value of options. They would insist, however, that the only vehicle for arriving at the relevant valuations is to examine whether the options have emerged from the "impersonal" competitive process. ${ }^{90}$

\footnotetext{
${ }^{89}$ See Hayek, note 43 at 76.

${ }^{90} \mathrm{Of}$ course, advocates of a free society hasten to add that the range of choice would be greater in such a society that it could ever be under conditions of economic planning. See Hayek, note 43 at 70-71.
} 


\section{Private collective self-determination}

Political choices interfere with the private autonomy of those who are defeated in a vote. A system that favors market solutions, by contrast, supposedly gives private autonomy its due. Accepting the constraints that originate as a cumulative effect of market transactions is how one pays respect to the free choices of others. ${ }^{91}$ Hence, the majority of people who have to work harder under competitive conditions because a smaller number has raised the bar of achievement thereby recognizes, normatively, the existence of private autonomy under conditions of reciprocity. Consequently, the limits on opportunities that one experiences in a free society are particular instances of a certain form of collective self-determination. It is the collective selfdetermination among individuals who use contracts to co-ordinate their actions and do not address the cumulative side-effects to which these actions give rise.

Generally, one is collectively self-determining if one allows oneself to be determined by an entity other than oneself of which one is, nonetheless, part. ${ }^{92}$ If everyone conceives of him- or herself as one market participant among equal others and, therefore, identifies with being active within a web of horizontal transactions one is self-determining inasmuch as one is part of the web in every instance in which one readily adapts to the situation created by the web. As a matter of reciprocity, whatever is done by someone within the web counts as what could have been done by oneself. Consequently, aggregate effects are not alien, they are the social manifestation of the private autonomy of all to whom one belongs as an equal. This private form of collective self-determination universalizes the disjointed co-existence of

\footnotetext{
${ }^{91}$ See Hayek, note 85 at 120-121, where Hayek explains that those who suffer from the effects of new competition have already been the beneficiaries of a prior competitive situation. Hence, this is a justification of competition that draws on reciprocity.

${ }_{92}$ More precisely put, it presupposes the identity of identity and difference.
} 
individuals. The "compulsion of circumstance"93 is therefore jointly authorized by individuals who co-ordinate their actions horizontally but do not co-operate vertically in order to address them. People who experience themselves as disempowered by circumstance while conceiving of themselves as private individuals merely encounter their own will: volenti non fit iniuria. Their circumstances are mediated by the "impersonal" mechanism of the market, which, rightly understood, reflects collective private selfdetermination, i.e., the mutual recognition of private autonomy. Its impartiality is actually indifference with regard to how market situations affect individual lives. It overrides moral intuitions concerning well-being or justice that might beset people when they learn about ill-fated neighbors or friends. ${ }^{94}$

From that perspective, it can be seen that Marxists were mistaken in describing the situation of labor as a lack of freedom or as a form of alienation without specifying any further what, for a situation of self-alienation to arise, a human being has to be taken to be. ${ }^{95}$ If human beings are essentially private (i.e., "individuals") there is no meaningful way of establishing in which respect they are alienated from themselves given that humans signal through their participation in a web of transactions that they mutually recognize one another's private autonomy.

\footnotetext{
93 See Hayek, note 43 at 19.

${ }^{94}$ See ibid. at 92-93.

95 Of course, Marxists always assumed that there was more to freedom than private autonomy. See Wood, note 39 at 50 .
} 


\section{The impression of naturalness and the improvement imperative}

One might suspect that this somewhat better elaboration of the reply to the challenge of democratic decision-making is vulnerable to an objection. Doesn't such a collective individualism tacitly favor that form of life which is likely to prevail under competitive conditions? Whoever possesses sufficient flexibility and stamina is likely to succeed. Indeed, if people want to keep their head above the water they have to have two properties, the possession of which is a duty towards themselves: agility and adaptability. ${ }^{96}$ While it is clear that not everyone will be able to develop these properties equally, they are still not part of every way of leading a life. Many versions of living a meaningful life are more contemplative. They are difficult to sustain under conditions of economic liberalism. It would appear, therefore, that economic liberalism is tacitly illiberal. ${ }^{97}$

This objection would be entirely ill-founded if it were true that there is no alternative way of being neutral among ways of life than the competitive order. The market would then simply represent the "right" type of order. 98 Indeed, for a steadfast defender of the market economy the guidance that people obtain from prices bespeaks a voice of reason that is incapable of being articulated by, or embodied in, any human being or any group. ${ }^{99}$ Quoting from Hayek: 100

\footnotetext{
${ }^{96}$ See my 'The Social Question in a Transnational Context' LSE European Institute Working Paper, http://www2.lse.ac.uk/europeanInstitute/LEQS/LEQSPapers.aspx.

${ }_{97}$ This objection is empirically sound. Yet, the advocates of a free society could still reply that agile and adaptable people might be confronted with the same dilemma were they to find themselves in a society of slackers. They would be shunned by everyone else and willy-nilly forced to live like everyone else. Nevertheless, what competition does is that it homogenizes. And it forces people to cater to the projects of others.

${ }^{98}$ See Hayek, note 85 at 115-120.

${ }^{99}$ See ibid., at 116

100 Note 73 at 15.
} 
[...] [H] uman Reason, with a capital $R$, does not exist in the singular, as given or available to any particular person, as the rationalist approach seems to assume, but must be conceived as an interpersonal process in which anyone's contribution is tested and corrected by others.

Only the decentralized co-ordination of choices can help everyone to achieve what they desire. Adaptation to necessities means doing the right thing.

The elevation of the competitive markets to the state of natural law ${ }^{101}$ must, however, fail unless it is supported by an attractive normative principle. ${ }^{102}$ Remarkably enough, markets obscure this link to a justification. As has long been observed by Marx, ${ }^{103}$ market relationships are surrounded with an aura of naturalness. The existence of commodities and prizes lends man-made social relationships the appearance of relations among things, ${ }^{104}$ for example, as the relation between a "job" and a required set of "skills".

The apparent naturalness of the market leaves its mark on how people exercise their freedom. In any competitive context the key to success is being better than others ("improve or die"). People not only have no choice of their options, they even need to make a special effort to excel at what man-made necessity leaves them little choice but to do. In a situation where not only resources but also consumer demand is scarce, demand needs to be generated. Banks, for example, have become particularly inventive at offering customers services that they could have never imagined themselves. But once the service has been invented, human greed makes it almost irresistible.

\footnotetext{
${ }^{101}$ Hayek, note 85 59-60, expressed reservation as regards classifying his evolutionary approach to order as natural law. However, since Hayek clearly seeks to obtain normative guidance from the type of order that is characteristic of markets, it makes sense to refer to his approach as a natural law theory.

102 In the case of Hayek it is difficult to see whether his celebration of markets is based on the normative principle that on average and in the long term everyone is likely to be better off or on the admiration for the type of being that a market is. If the latter were the case, Hayek would provide us with a normative ontology of the market economy, which must strike one as an almost medieval undertaking.

${ }^{103}$ See Karl Marx, Das Kapital, Marx-Engels-Werke (Berlin: Aufbau Verlag, 1968) vol. 23 at 100.

${ }^{104}$ See Georg Lukács, Geschichte und Klassenbewußtsein. Studien über marxistische Dialektik (10th ed., Neuwied: Luchterhand 1988) at 174.
} 
Technology, owing to its cunning appeal to the infantile parts of our soul, is highly successful at creating necessities that profoundly alter our lives. This is part of capitalism's erotic appeal. The reward for having permanently to improve in random tasks resides in enjoying the unexamined life of the consumer of gadgets and other amenities of life. Capitalism is as brutal as it is charmingly shallow.

\section{The world of individuals}

The somewhat better elaboration of the reply would have us perceive situations that are the aggregate effect of voluntary transactions as endorsed by the collective self-determination of individuals who do not live in community with, but merely among, others. This self-determination is mediated by reciprocity. Everyone could be in anyone's position in the web of transactions. In addition, the somewhat better elaboration would also find political choices unobjectionable if they were taken unanimously. ${ }^{105}$ This is tantamount to reducing the political to the private. Such a reductionism is nowhere more clearly articulated than in how Friedman explains the meaning of political freedom: ${ }^{106}$

Political freedom means the absence of coercion of a man by his fellow men.

This is an outright equation of political with private freedom. Nowhere is it more evident that matters such as speaking in public, campaigning and voting are not on the radar screen of the advocates of a free society (campaign contributions are, to be sure).

105 Quite tellingly, Hayek, note 43 at 45, 47, argues against the democratic control of the economy by pointing out that there would not be enough agreement on economic matters even tough it would be necessary for parliament to exercise a steering function.

106 Friedman, note 76 at 15. 
Besides self-reliant adaptation to market situations, unanimous voting is the other form of collective self-determination that is compatible with private freedom. While the first is indirect and endorses situations because they arise as a consequence of a web of transactions, the second is direct (and raises the specter of collective responsibility). ${ }^{107}$ They are not on an equal footing. It is not likely that people will unanimously agree on how to alter the circumstances of their choices in order to align them with how they want to live. Given the diversity of human temperaments and plans such a vote would hardly ever be taken. Hence, individuals, owing to their isolation, are destined to enjoy their freedom of choice in adaptation to non-chosen circumstances. If they were to examine their life as a potential whole they would possibly find themselves faced with the prospect of living how they do not want to live even though this could be changed by political means. Respect for the private autonomy of others, however, puts such a change de facto out of reach.

This suggests that paying respect to private autonomy consistently exacts public autonomy as its price. Advocates of a free society, however, do not perceive a loss. For ontological reasons, political self-determination is quite inconceivable for them. In their view, collective self-determination is always self-determination by individuals and comes in two forms: first, adaption to markets, since this reconciles individual freedom of choice with the same freedom of equal others; or, second, unanimous decisions.

\footnotetext{
107 What is remarkable about the first form of collective self-determination is that it endorses something that is not willed by anyone. It is fundamentally passive, in contrast to political selfdetermination that involves the passive acceptance of what is willed by others.
} 


\section{Hegel's insight: Authority by virtue of necessity}

Unanimity can be mediated by a concurrence of either desires or insights. While the former are by definition individual possessions, the latter are socially conditioned. The knowledge that can underpin and necessitate unanimous decisions is substantially and formally "social" in its nature.

First, insight into the socially conditioned nature of individual pursuits requires the recognition of some form of authority that stabilizes the mutually beneficial web of interactions. As Hegel famously explained:108

The selfish end in its actualization, conditioned in this way by universality, establishes a system of all-round interdependence, so that the subsistence [Subsistenz] and welfare of the individual [des Einzelnen] and his rightful existence [Dasein] are interwoven with, and grounded on, the subsistence, welfare and rights of all, and have actuality and security only in this context. - One may regard in the first instance as the external state, the state of necessity and of the understanding.

Hegel's Not- und Verstandesstaat, the intellectual promulgation of which he attributes the contractualist tradition from Hobbes to Fichte, is underpinned by individual insight into what is instrumentally necessary in order to sustain a life of recurrent maximizing choices that involve the mutual recognition of choices made by others. The insight into the necessity of authority is socially mediated in that it recognizes the integrity of the web of transactions as a necessary condition of freedom of choice. It reveals that such freedom is socially constituted and sustained.

Second, insight itself is socially mediated formally in that knowing is a social activity, not only in the sense that knowledge becomes more solid if tested through the exchange of experience and argument, but also in the sense that one depends for one's own knowledge vitally on the knowledge of others.

108 G.W.F. Hegel, Elements of the Philosophy of Right (trans. H.B. Nisbet, Cambridge: Cambridge University Press, 1991) at 221 (§ 183). 
These others are often in a better position to know things than one is oneself. Individuals understand that people with expertise have to have a say on matters concerning the integrity of market transactions and the management of risks. Consequently, the rise of administrative authority is a built-in feature of a free society. People gladly defer to who can rightfully claim to have better knowledge for it lifts various burdens off their shoulders. The concurrent deference of individuals serves as a substitute of unanimous voting on the basis of insight. It is knowledge of no knowledge combined with the recognition that things have to be done by people who know how to do things well. Public problems become resolved, therefore, not on the basis of political choices but on the ground of whatever purports to be greater insight. ${ }^{109}$ Rational deference is the bedrock of the administrative state. Its claim to authority rests on the idea that insight into their limited knowledge and problem-solving capacity gives people a reason to yield to the determinations made by expert bodies. ${ }^{110}$

Authority by virtue of necessity - the Not-und Verstandesstaat-is an extension of the collective private self-determination of individuals. This must not be mistaken for political self-determination, which, by contrast, also involves yielding to the determination of others (or to one's own determination in a political capacity). What reconciles, in the case of political self-determination, the passivity of being determined with the activity of determining is not seeing oneself as part of a web of transactions but rather as a part of a place shared with concrete others. ${ }^{111}$ This presupposes a conception of sociality that is alien to the advocates of a free society, for they conceive of the web of market transactions not as a place. Subjects of various webs are, borrowing from Constant, “individuals, lost in an unnatural isolation, strangers to the

109 On the "police", see ibid. at 260 (§ 231).

110 This is not the whole story. See my forthcoming 'Accidental Cosmopolitanism: Citizenship at the End of History'.

${ }^{111}$ See my ‘On Cosmopolitan Self-Determination' (2012) 1 Global Constitutionalism 405-428. 
place of their birth, without any contact with the past, living only in a hurried present, scattered like atoms on a vast plain."112 Put differently, these webs are not polities. Conceiving of oneself as an element of a place, by contrast, requires seeing oneself as part of a whole that does not flow out into the infinity of horizontal transactions. It actually presupposes the use of the intuitive understanding in order to grasp a bounded totality. ${ }^{113}$

\section{Individual responsibility}

The type of ordering that is preferred by the advocates of a free society, even though not defended on the ground of some moral theory, is prone to foster a remarkably moralistic attitude. This has to do with the abdication of responsibility on the part of society, which is even considered to be a chimerical entity by some of its advocates. ${ }^{114}$

If nobody is responsible for what happens on markets, the responsibility to influence or alter one's situation and to exercise requisite foresight automatically devolves to the individual. ${ }^{115}$ This responsibility is unlimited. If your country goes bankrupt you are responsible to deal with the consequences affecting you because you could have decided to move to another country beforehand.

It should be noted, however, that this type of "responsibility" is based on nothing other than the absence of social responsibility and the existence of some trivial instrumental relationship between individual wants and their satisfaction. Imagine, for example, that a party has littered a public picnic

\footnotetext{
112 Constant, note 11 at 255.

113 For a further elaboration of this basically Goetheian idea, see Förster, note 52 at 256-259.

114 See Hayek, note 98 at 70; Margaret Thatcher, Interview with Women's Magazine, 31.10.1987, available at http://www.margaretthatcher.org/document/106689.

115 See Bröckling, note 74 at 93-94.
} 
area. The next person wishing to enjoy it needs to clean up the mess that has been left by others. It is this person's "responsibility" for the simple reason that nobody else wants the area to be clean. But this does not mean that the person has incurred an obligation towards others. That people are responsible for themselves means only that they have to make an effort if they wish to do well. Young adults who struggle to obtain an education by doing hard work in order to be able to afford it merely clean up the mess that society has left for them.

But this difference in the meaning of responsibility does not prevent the folks living in a free society from using individual responsibility in strongly normative terms. It helps to rationalize their lack of regard for others. People are responsible for their lot. They deserve to be in the situation that they are in.

\section{The heart of the matter}

I conclude these fragmentary observations concerning capitalism and freedom with a few hints as to how they could be usefully amended.

First, the argument would benefit from an exploration of Robert Hale's contention that the laws governing a market economy empower people to engage in coercion. Rather than being a zone governed by voluntary agreement, a market economy is basically a place where the have-nots eventually yield to threats. ${ }^{116}$

116 See Fried, note 79 at 56-57. 
Second, Max Weber ${ }^{117}$ observed quite perceptively the existence of a functional equivalence between governance on the basis of authority and governance by creating situations in which people act in response to competitive pressures. Indeed, the process of governance is concealed from the governed so long as they believe to react merely to situations whose constitution cannot be imputed to anyone because they appear to be essentially side-effects ("externalities"). The latter form of governance may, indeed, be more conducive to the development of self-discipline. Furthermore, Weber also recognized that organized businesses are essential to economic survival in market economies. Hence, a need for "leadership" and hierarchy arises from their midst. This explains also why the Tories' obsession with privilege and deference is compatible with the liberal support of free markets. While some are calling the shots, the large majority is forced to obey. Not by accident, hence, a capitalist economy used to be surrounded by an authoritarian air, at least until its harsh male tone was mitigated in the course of the revolution in communication. ${ }^{118}$ The authoritarianism has now largely been internalized into the maxim of permanent self-improvement, while unpleasant things are done to employees with an expression of regret.

Third, looking beyond the problems of mere economic liberalism and extending the analysis to liberalism generally it would be necessary to take the profound work of the German philosopher Christoph Menke into account. ${ }^{119}$ In his view, liberal equality invariably collides with human freedom since it expects people to adjust their own good to what is compatible with a liberal conception of justice. The rules and principles of fairness expect people to adjust their good in light of contingent

\footnotetext{
117 See Max Weber, Economy and Society (trans. E. Fischoff et al., Berkeley: University of California Press, 1978) vol. 2 at 731.

118 See Eva Illouz, Saving the Modern Soul: Therapy, Emotions, and the Culture of Self-Help (Berkeley: University of California Press, 2008) at 72-77.

${ }^{119}$ See, most notably, his Tragödie im Sittlichen: Gerechtigkeit und Freiheit nach Hegel (Frankfurt aM.: Suhrkamp 1996).
} 
opportunities. Consequently, people are expected to dispose of their most authentic longings. Law and justice ignore the difference between how individuals experience their longings and how it casts them into the role of equal choosers. ${ }^{120}$

Even though the analysis is incomplete, I conclude, nonetheless, with the confidence that the major point, which is a very elementary one, has emerged clearly enough.

The first horn of the dilemma was that human emancipation appears to confront modern individuals with an overbearing demand for ancient liberty. The second horn consisted of the problem that gave rise to the desire for emancipation in the first place, namely the subordination of human beings to self-made necessity. It has now turned out that this necessity is experienced as heteronomy only if humans conceive of themselves as political beings.

Contrary to what has been taken for granted by Marx, it is not clear yet why people would have reason to experience themselves as political beings (and, $a$ fortiori, "as species beings"). This is all the more doubtful given that a capitalist society is capable of generating the type of individual that is compatible with it. This, at any rate, must have been the core idea underlying Marcuse's concern with a whole syndrome of disempowerment. ${ }^{121}$ It arises when the advanced industrial society succeeds over the experience of alienation and absorbs all transcending forces by making them its own. The remaining energies of rebellion feed then into the reinforcement of conformity and submission. We shall return to this idea in the context of our discussion of empowerment.

\footnotetext{
120 See ibid. at 259-260, 296-298.

121 See Herbert Marcuse, One-Dimensional Man. Studies in the Ideology of Advanced Industrial Society (Boston: Beacon Press, 1964) at 9, 145.
} 


\section{The mute point of economic liberalism}

What advocates of a free society would have to concede, nonetheless, is that there is a clash between the "tough love" of individual responsibility, on the one hand, and rational insight into authority by virtue of necessity, on the other. Rational insight into the inevitability of permitting those who are in the know to rule our lives is always riddled with the paradox that it cannot determine where our ignorance has to come to an end. Under the impression of overwhelming complexity one is easily led to the conclusion that the scope for exercising one's own judgment must be dramatically narrow. As a result, there is not only an inclination to concede to administrative bodies more authority than they perhaps deserve but consequently also increasing interference with private freedom by anonymous authorities that lack proper accountability. That the fate of states and their currencies is in the hand of rating agencies is a case in point. Evidently, private liberty has an authoritarian face when it comes to using socially validated insight for the benefit of all.

Since neither members nor advocates of a free society can conceive of society as a collective entity there is no other way of establishing authority than by conventional yielding to this or that "site" with problem-solving authority. This matches the situation envisaged by the most radical proponent of legal pluralism. Various authorities exist side-by-side, but lack an anchor in one overarching constitutional framework. ${ }^{122}$ The anonymity of their constitution is inherited from the anonymous "authorship" of situations that arise as a result of market transactions.

122 See Nico Krisch, Beyond Constitutionalism: The Pluralist Structure of Postnational Law (Oxford: Oxford University Press, 2010) at 100. 
In principle, the acceptance of authority by virtue of necessity is an extension of collective private self-determination. This includes concurrent and conventional individual deference to administrative bodies. However, since concurrent deference would not make any sense if it were not mediated by persons' taking their cue from the deference that they observe in others, it also marks the moment at which private autonomy might turn into political autonomy. One does as all others do. The authority of sites is conventional. Conventions, however, are a not publicly reflected form of collective selfdetermination among members of a group. This is revealed by the fact that if we explain what a convention demands we say that this is how "we" do things "here". That is, once we get to conventions, we are reaching the ground of political self-determination. We posit a collective subject and a place. However, we do so entirely passively. We treat, when bringing the convention about, the convention as a given. We are entirely passive. That is, we do not perceive it as our product. Conventions are political liberty merely "in itself".

Transcending private self-determination may be necessary, ironically, in order to contain, if humanely possible, the self-subversive tendencies of capitalism which are not least manifest in the disconnect between the elite's profit interest and the general interest in system survival. ${ }^{123}$ These tendencies may make it unavoidable to shoulder some joint responsibility. Whoever, therefore, moves beyond a system of government that merely combines free markets, the administration of justice and the regulation of risks - justice and administration being the hallmarks of the Not-und Verstandesstaat-leaves the

${ }^{123}$ See Wolfgang Streeck, 'Taking capitalism seriously: towards an institutionalist approach to contemporary political economy' (2011) 9 Socio-Economic Review 137-167, at 150-151, 158. 
ideological precinct of economic liberalism. ${ }^{124}$ For such a move posits that, as mere market participants, people are alienated from their political being. ${ }^{125}$

\section{A not so dark European legacy}

Endorsing the priority of political over private freedom implies that in the respect that was most important to him, Hayek was wrong. It is not impossible to hold markets to account, in particular not for allegedly ontological reasons ("markets are not the kind of beings to which actions can be imputed"). Making markets responsible is a matter of creating governments that are responsible for markets. This is a trivial point. It is, nonetheless, of great significance, for it explains what has underpinned Western European social projects of the twentieth century. They were about finding a viable strategy for asserting the primacy of the political ordering of society without committing the fatal mistakes of "really existing socialism".

\footnotetext{
124 To expect governments to do more than guarantee the integrity and functioning of private exchanges means to move beyond the sphere that Hegel reconstructed under the name of civil society. The idea of moving beyond economic liberalism is, however, driven by the hope that political freedom, even though ennobling in its own right, is able to restore the private freedom that people lose in a market society. This is the emancipatory promise that is shared by socialism and other forms of overcoming economic liberalism. The late Marx most famously described it in the following terms (Capital vol. 3): "In fact, the realm of freedom actually begins only where labour which is determined by necessity and mundane considerations ceases; thus in the very nature of things it lies beyond the sphere of actual material production. Just as the savage must wrestle with Nature to satisfy his wants, to maintain and reproduce life, so must civilised man, and he must do so in all social formations and under all possible modes of production. With his development this realm of physical necessity expands as a result of his wants; but, at the same time, the forces of production which satisfy these wants also increase. Freedom in this field can only consist in socialised men, the associated producers, rationally regulating their interchange with Nature, bringing it under their common control, instead of being ruled by it as by the blind forces of Nature; and achieving this with the least expenditure of energy and under conditions most favourable to, and worthy of, their human nature. But it nonetheless still remains a realm of necessity. Beyond it begins that development of human energy which is an end in itself, the true realm of freedom, which, however, can blossom forth only with this realm of necessity as its basis. The shortening of the working-day is its basic prerequisite.".

125 See (quoting Erich Fromm) Rahel Jaeggi, Entfremdung: Zur Aktualität eines sozialphilosophischen Problems (Frankfurt aM: Campus, 2005) 42.
} 
What they were up to was finding an alternative to human emancipation that is consistent with the modern form of political freedom. ${ }^{126}$

Admittedly, nowhere else has the quest for the glory of the political been as bizarre and inhumane as in the context of European fascism. Nowhere else has, at the same time, the attempt to rescue human life from the grip of commodification given rise to such a number of diverse and relatively successful social models as in Western Europe. Nowhere have Christian parties, in particular, seen a greater hour than during Europe's twentieth century. ${ }^{127}$

In many respects, the modern welfare state represents an equivalent of the change from ancient liberty to representative democracy in the field of solidarity. Instead of involving the "Proletarian state" fully in extending concern and care for others, mechanisms are introduced to restore human dignity vis-à-vis humans who have lost their connection with one another in the seamless webs of collective private self-determination. Thus understood, the social welfare state "constitutionalizes" the Not- und Verstandesstaat.

The point is not to establish central authority over markets but to make dependence on the market mechanism less oppressive. The social welfare state is the application of the principle of negative liberty, which constitutes the market economy, to the market economy itself. Like the negative liberty of economic liberalism it depends on something positive for its realization. Economic freedom rejects "state regulation" in order to enjoy the liberties defined by private law and protected by the administration justice. Similarly,

\footnotetext{
${ }^{126}$ Its focus does not rest on creating the conditions for the emergence of a "total human being" whose abilities and ambitions would not be blemished by the discipline of the division of labour. See Iring Fetscher, Karl Marx und der Marxismus: Von der Ökonomiekritik zur Weltanschauung (4th ed. Munich: Piper, 1985) at 57, 229.

127 On the consensus that capitalism had to be contained by the state, a consensus that emerged in the era after the Second World War, see Tony Judt, Ill Fares the Land (New York: Penguin Press, 2010) at 46-49.
} 
social rights reject collective private self-determination and give people access to enjoy security on the basis of solidarity, that is, within systems designed to let the bad risks benefit from the participation of the good risks. In contrast to human emancipation, which would have ideally involved the "positive" freedom of participation in the exercise of joint control, the welfare state creates independence-freedom from interference with life by freedom of contract-by targeting the most salient risks and alienating consequences that arise when humans sever the ties that connect them with one another. The sick are not dependent on freedom of contract in order to have health insurance; the less well-off are not dependent on amassing wealth in order to be able to afford retirement; the unfit are not dependent on selling their own labor for their survival.

With this emphasis on negative liberty from markets, the social welfare state stops short of realising a thick human community where individuals might be fully reconciled with their "species being". The idea is that attempts at creating such a community would merely modify, but not mitigate, alienation and submission. Instead of aiming at full liberation it offers disentrapment or, put differently, decommodification. ${ }^{128}$ Instead of getting everyone, potentially, involved in the life of others, it promises individual liberation by alleviating the socially incarcerating effects of adaptation and dexterousness. Human dignity is restored vis-à-vis collective private self-determination. Unemployment benefits, pension payments and health care signal that individual life is not a commodity that society can dispose of as soon as demand has abated. ${ }^{129}$

\footnotetext{
128 See, generally, Gøsta Esping-Andersen, The Three Worlds of Welfare Capitalism (Princeton: Princeton University Press, 1990) 21-22.

129 The welfare state, nonetheless, is consistent with individualism and with shifting the focus of life towards the private sphere. This shift is always likely to undermine its authority since it gives rise to a plain and potentially derogatory service mentality on the part of its clients.
} 
Even though the welfare state is evidently compatible with liberal democracy, the social position that becomes universalized as the standard position of a member of society is no longer the property-owing citizen but the free laborer. The paradigmatic experience is not self-reliance, but self-alienation. The elementary social act is not freedom of choice but the reification of human nature into a resource. The most elementary threat does not originate from others pursuing their self-interest but rather from a structure of interaction in which one participates and from which one expects to benefit. Society is not perceived as the combined and somewhat haphazard result of an association of free individuals but as the unwieldy product of man-made, and therefore false, necessity. It is the self-made necessity revealed in a market-society's relentless appetite for agility and adaptability.

The partial decommodification of life-its disentrapment vis-à-vis collective private self-determination - can only be a common achievement. By virtue of being more than a mere fortunate effect of uncoordinated behavior it presupposes boundaries. The universality of the problem posed by the system of needs requires particularistic solutions simply because they cannot emerge from horizontal dealings. If the number of beneficiaries could without anything further grow at any time, the reciprocity of commitments would easily be undermined. If the individuals whose contributions go into redistribution - the wealthy, the healthy, and the young - could easily opt out and make arrangements among themselves or immunize their wealth and capital from the grip of taxation, the antithesis to market liberalism could not be sustained. It is an error to suppose that the particularity with which welfare states draw on "common sympathies" for their effectiveness is a deficient manner of addressing a universal problem. Rather, the particularity of bounded systems is justified inasmuch as it provides the key to dealing 
effectively with a universal problem. It inherits, dialectically, its universality from what it addresses.

Seeing the welfare state as the alternative to human emancipation that fits our modern understanding of liberty allows one to understand its significance. It has forever altered the meaning of the social question from relieving the lot of the poor to realizing a more modest project of emancipation. This is a historical sea change, which has had as its historical background the successful attempt to garner broader support from the middle class for social policy. ${ }^{130}$ It has given rise to a cluster of forms of life in Western European countries whose historical significance cannot be easily erased. In the collective memory of European history it has been inscribed as a singular achievement, and often, if only loosely, summarized under the name of "social justice".

\section{The European Union}

In order for the Union to be seen as coextensive with this quest for a "third

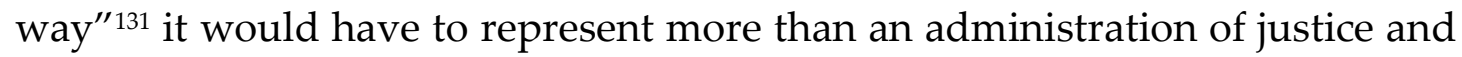
a regulatory state. One would have to be able to link it to the pursuit of social justice. ${ }^{132}$ Alas, this is a jacket that does not fit the Union well. The Union lacks most of the competence in the social sphere. ${ }^{133}$ Even where formal powers are

\footnotetext{
130 See Judt, note 127 at 52-53.

131 See my short comment, ,Und was fehlt eigentlich? Eine Anmerkung zu Europas politischem Erfahrungsraum' In Ch. Joerges et al (eds.), "Schmerzliche Erfahrungen der Vergangenheit" und der Prozess der Konstitutionalisierung Europas: Rechts-, Geschichts- und Politikwissenschaftliche Beiträge (Wiesbaden: SWV, 2008) 144-149

132 See

133 See Catherine Barnard, 'Social Policy Revisited in the Light of the Constitutional Debate' in C Barnard (ed.), The Fundamentals of EU Law Revisited: Assessing the Impact of the Constitutional Debate (Oxford: Oxford University Press, 2007) 109-151.
} 
available they cannot be exercised owing to a problem-solving gap. ${ }^{134}$ Where the Union has been successful, such as in the field of anti-discrimination policy, is has shifted the focus from distribution to inclusion and thereby become more compatible with the mindset of neoliberalism. ${ }^{135}$ Even worse, the recent developments of Commission proposals and the case law of the European Court of Justice betray a strong preference for a liberal social model. ${ }^{136}$ It makes it difficult to sustain other forms of organizing capitalism that are part of the national traditions of the member states. Finally, monetary union appears to have resulted in the rise of a collective Bonapartism that benefits bankers and harms low earners in the Union. ${ }^{137}$

All in all, it is fair to say that the Union is not treading along with most of the Member States on this alternative and more circumspect path towards emancipation. For those who are already critical of the Union's system of political economy this outcome will not come as a surprise. As an instance of an international federal system, the Union appears to be consistent with an essential element of the neoliberal program. ${ }^{138}$ Neoliberalism is not a champion of social justice, in particular not of social equality. ${ }^{139}$

But perhaps the emancipatory promise of the European Union needs to be sought elsewhere. For if there were nothing to find it would remain inexplicable why sober minds believe, as Beck and Grande ostensibly do, ${ }^{140}$

\footnotetext{
134 See Fritz W. Scharpf, 'The Joint Decision Trap: Lessons from German Federalism and European Integration' (1988) 88 Public Administration 239-278; idem, Democratic Legitimacy under Conditions of Regulatory Competition: Why Europe Differs from the United States' in K Nicolaidis \& R Howse (eds.), The Federal Vision (Oxford: Oxford University Press 2001) 355-374.

135 Or this is what I have argued. See my Engineering Equality: An Essay on European AntiDiscrimination Law (Oxford: Oxford University Press, 2011).

${ }^{136}$ See Martin Höpner \& Armin Schäfer, iidem, 'Eine neue Phase der europäischen Integration: Legitimitätsdefizite europäischer Liberalisierungspolitik' in M Höpner \& A Schäfer (eds.), Die politische Ökonomie der europäischen Integration (Frankfurt aM: Campus Verlag, 2008) 129-156. 137 See merely Hauke Brunkhorst, ,Kollektiver Bonapartismus', http://www.eurozine.com/articles/2012-04-17-brunkhorst-de.html.

138 See Hayek, note 73 at 28.

139 See ibid. at 22, 31.

140 See Ulrich Beck \& Edgar Grande, Das kosmopolitische Europa (Frankfurt aM, Suhrkamp, 2004).
} 
that the Union is the last remaining utopia (unless they are easily swayed by deflated utopian energies).

Indeed, the Union appears to have done something new. The Union has put the individual at the center. Lawyers have long been aware of this. ${ }^{141}$ Hence, when the project of social justice turns out to be ill suited to explain the Union's potentially emancipatory appeal, perhaps one should examine how the Union articulates its concern for individuals vis-á-vis traditional collectivities. Emancipation from traditional social powers - would this not be an empowering program?

A complacent reference to the protection of rights, however, alone will not do to mark the Union's achievement. ${ }^{142}$ One would like to know what it is that is valued about people inasmuch as they are individuals in order to see how the Union might contribute to setting this valued element free. While several candidates for promoting individuals can be dismissed as irrelevant for the Union, such as Nietzsche's perfectionism, others recommend themselves for historical reasons. I shall examine them in turn.

I surmise that if there were a story to tell about European humanity beyond the twentieth century it would most likely see Europeans historically moving on from human emancipation via social justice towards empowerment. The question is, of course, whether it will have a happy end.

\footnotetext{
${ }^{141}$ See, for example, F. G. Jacobs (ed.), European law and the Individual (Amsterdam: NorthHolland Pub. Co,, 1976)

142 This explains, why the contributions by Williams and Neyer do not really get off the ground. See Andrew Williams, The Ethos of European Integration: Values, Law and Justice in the EU (Cambridge: Cambridge University Press, 2010); Jürgen Neyer, 'Justice, Not Democracy: Legitimacy in the European Union' (2010) 48 Journal of Common Market Studies 903-921.
} 


\section{Empowerment light}

What could it be over and above the sheer fact that people have rights that might prove that the European Union is committed to the individual?

There are many ways for societies to put the individual at the center. What this means depends on why one believes individuals to be special in contrast to the "mass" of people or some collective body. One reason may be their vitality and their ability to enjoy life in spite of its futility. Arguably, one candidate for what it takes to put the individual at the center would be some form of Nietzschean elitism, which would have the weak-natured serve the strong-natured and the mass of society dedicated to the breeding (Züchtung) of great creatures (we cannot be sure that this was Nietzsche's idea). Presumably, however, this is not the type of individualism that the European Union would publicly countenance, let alone endorse on its website.

There is, however, an individualism that is more likely to fit the Union, namely that potentially wearisome, but democratically tamed Nietzschanism which perceives people capable of inventing and reinventing themselves as if their life and biography were pieces of art. ${ }^{143}$ One merely needs to downplay the playfulness inherent in this idea and shift the emphasis on individual choice, and all of a sudden it begins to resemble closely what the late Thomas Franck considered to be the mark of law in the age of individualism.

According to Franck, the contemporary international system has given rise to an "emerging right to individuality", 144 which is concomitant to the demise of the nation as the definer of who people are. The new individualism perceives persons as choosing their own, "unique" identity without regard to "law,

\footnotetext{
${ }^{143}$ See Alexander Nehamas, Nietzsche: Life as Literature (Cambridge, Mass.: Harvard University Press, 1985)

144 Thomas M. Franck, The Empowered Self: Law and Society in the Age of Individualism (Oxford: Oxford University Press, 1999) at 1.
} 
custom, culture and religion". They "design" their "freely chosen identities", thereby drawing on a range of available options that has broadened exponentially. ${ }^{145}$ Franck seems to believe that the right to individuality, which is more or less the result of the confluence of a number of human rights, ${ }^{146}$ is most accurately epitomized by the right to privacy. ${ }^{147}$ Most fundamentally, asserting one's individuality presupposes the right to be left alone by traditional communitarian powers, such as states, nations or religious congregations. It is from this perspective that Franck's remark becomes intelligible that the "new individualists of the late twentieth century" no longer draw a line with regard to "the" other, but "identify with the alien other" ${ }^{148}$ If one identifies with the alien other one regards oneself as someone who does not belong and stands aloof from territorially or biogenetically defined ties. ${ }^{149}$

If this were the full story, Nietzsche would have been proven right who sensed already in the nineteenth century that Europe was to become more "artistic". ${ }^{150}$ If people had the power to pick and choose their identity ad libitum such identity would have its ground only in a choice to adopt it. Once freely chosen, it could be equally freely relinquished. This infuses identity with irony, for there is nothing serious about an identity that is not appropriated in a process of discovery and recognition. ${ }^{151}$ People would invariably always merely play at being someone. The identity that is worn as a mask would barely conceal the arbitrariness of choice.

\footnotetext{
145 See ibid at 255.

146 See ibid. at 280 .

147 See ibid. at 255, 283.

148 See ibid. at 1.

149 See ibid. at 2.

150 Siehe Friedrich Nietzsche, Die fröhliche Wissenschaft, Kritische Studienausgabe (ed. G. Colli \& M. Montinari, Munich: dtv, 1988), vol. 3, at 595-597.

151 Remarkably, Richard Rorty was quite aware of this. See his Contingency, irony, and solidarity (Cambridge: Cambridge University Press, 1989) at 41-43.
} 
But, of course, this is not the point that Franck wants to make. He states unmistakably that the "former enemies of individualism"-state, church, social class etc. - are now under an obligation "to play an active role in empowering everyone to realize their full potential in the pursuit of personal self-definition"152. This suggests that adopting an identity is neither a matter of whim nor an act of radical, Sartrean choice, but rather a process that requires discovering one's "potential".

Thus understood, resting the focus on the individual would mean that the Union has an active role to play in helping individuals to succeed at becoming who they have the potential to be. This idea is, indeed, also known under the name of "empowerment". It is, however, empowerment in a mild and less radical form since it does not yet embrace the categorical imperative of selfactivation, to which we shall return below.

The idea that there is something in everyone waiting to be elicited and developed is a highly abstract and perhaps even relatively empty idea. It is abstract because it does not-at least not on its face-take into account that we discover what we can be by virtue of being invested in practices and sharing ambitions with others. ${ }^{153}$ There is nothing in us unless we discover it from within the social world that we inhabit. The idea is also perilously close to being empty because it does not address the problem that certain potentials are more easily realized than others.

152 See Franck, note 144 at 256.

153 See Jaeggi, note 125 at 197-198. 


\section{Personalism}

Franck's statement of empowered individualism is reminiscent of a religiously inspired commitment to the human person that appears to have had some influence on the invention of modern human rights. ${ }^{154}$ It was also an element of the beliefs professed by some of the people who were instrumental in the founding of the European Community. ${ }^{155}$ It had been most prominently expressed in the writings of the French Catholic philosopher Jacques Maritain, but it is not at all limited to his work.

The set of beliefs is called "personalism". ${ }^{156}$ Generally, personalism is rather vague with regard to its practical implication. At any rate, it is socially much less radical than earlier versions of twentieth century Christian social doctrine. ${ }^{157}$ At its heart, it attempts a "balancing act"158 between the extremes of collectivism and unbridled individualism. It emphasizes the ontological distinctiveness of persons and their dignity. ${ }^{159}$ Persons are "somebody" and not "something". Dignity invests them with inestimable worth. They are capable of self-determination.

As part of God's creation, persons ought to use their freedom responsibly, not least in order to realize their own ends within the larger scheme of things. Personalists claim that owing to the dignity of persons nobody may be fully absorbed into a collective body and be turned into a mere instrument of the

\footnotetext{
154 See Samuel Moyn, The Last Utopia: Human Rights in History (Cambridge, Mass.: Harvard University Press, 2010) at 54, 65, 74, 76-77.

155 Major national politicians involved in the founding of the European Union were Christian Democrats (Alcide de Gasperi, Konrad Adenauer and Robert Schuman). See Jan-Werner Müller, Contesting Democracy: Political Ideas in Twentieth Century Europe (New Haven: Yale University Press, 2011) at 141.

${ }^{156}$ For a highly useful overview, see Thomas D. Williams \& Jan Olaf Bengtsson, 'Personalism' In Stanford Encyclopedia of Philosophy, http://plato.stanford.edu/entries/personalism. The former Pope Jean Paul IV is the author of various contributions to this type of philosophy.

157 See Müller, note 155 at 134. 140-141.

158 Ibid. at 140 .

${ }^{159}$ See Williams \& Bengtsson, note 156.
} 
community. Persons have to have rights. At the same time, personalists understand that human self-realization depends on the community, which is under an obligation to assist persons in realizing their ends. Persons can only flourish in communion with others. Society is not the haphazard agglomeration of antagonistic social atoms, but rather governed by the principles of solidarity and subsidiarity.

Personalism, therefore, offers a reply to Frank's concern that the right to be left alone needs to be complemented by a right "not to be left behind". ${ }^{160}$ The most salient problem of this doctrine is, however, its lack of specificity. It is unclear under which contextual conditions individuals would be allowed or even expected to realize their potential and what this potential actually is. Humans have, as Huizinga has long emphasized, a potential for play. Is this the reason why Europe has become more artistic?

The historically relevant portion of personalism is Christian in its orientation. One way of specifying a teaching that is in peril of easily becoming everybody's darling would be to develop the historical seeds of personalism in the Union further into the direction of the "project world-ethos". ${ }^{161}$ This would, for a change, connect Europe with the core of Christian teaching instead of associating, narrowly, the core of Christianity with how Catholicism deals with other faiths. ${ }^{162}$ It is to be feared, however, that the European Union is at least not yet prepared to take this step.

\footnotetext{
160 See Frank, note 144 at 256. Frank is strictly opposed to Küng's attempt to complement fundamental rights with fundamental duties. In his opinion, this "recalls the plaints of traditional authoritarians against personal freedoms" (257).

${ }^{161}$ See http://www.weltethos.org/data-en/c-10-stiftung/10a-definition.php.

162 The latter has been the focus of a rather bizzare pamphlet on "Christian Europe". See J.H.H. Weiler, Ein Christliches Europa: Erkundungsgänge (trans. F. Reimer, Salzburg \& Munich: Anton Pustet, 2004).
} 


\section{The Burkean individualist}

Sadly enough, it seems as though the search for what it means to take individuals seriously needs to return to the darker intellectual precincts of economic liberalism. What one discovers there, however, is astoundingly conformist. This, at any rate, is true of the individualism that was espoused by Friedrich August von Hayek as its true type.

In many respects, Hayek has the strangest view of individualism not least because he assimilates it to his vision of how a competitive order works. ${ }^{163}$ According to Hayek, "true" individualism humbly submits that no one is capable of knowing what is best for society as a whole for the simple reason that such a whole is incomprehensible. ${ }^{164}$ Since nobody can have this knowledge, it is better that people attend to their own business by drawing on what they know about their circumstances. ${ }^{165}$ This is how information is processed in a competitive order. What remote others seem to know about their own situation is represented in prices. If people take care of themselves they will inadvertently contribute to ends that are not part of their purpose ${ }^{166}$ and bring about, as a side-effect of their action, the spontaneous order of society. ${ }^{167}$ Individualism does not advocate selfishness. It merely recognizes the bounded nature of rationality. ${ }^{168}$ Moreover, it teaches respect for the benefits that an unplanned and spontaneous order creates for all:169

[...] [T] he fundamental attitude of true individualism is one of humility toward the process by which mankind has achieved

\footnotetext{
163 See, Hayek, note 73 at 6,14.

164 See ibid. at 8.

165 See Hayek, note 43 at 44 .

166 See Hayek, note 73 at 14-15.

167 See ibid. at 7.

168 See ibid. at 15.

169 Ibid. at 31. See also his statement of the fundamental principle of liberalism in Hayek, note 43 at 13: "[...] [I]n the ordering of our affairs we should make as much use as possible of the spontaneous forces of society, and resort as little as possible to coercion."
} 
things which have not been designed and understood by any individual and are indeed greater than individual minds.

Such a "Burkean" individualism ${ }^{170}$ is "antirationalistic". ${ }^{171}$ It concedes that individuals in coordinating their conduct need to rely on rules and institutions that cannot be created by individuals themselves because the type of reasonableness that they represent is untranslatable into the rationality of human action.

Respect for tradition is, hence, the most salient trait of individuals who are individualists in the Hayekian sense. What is more, as Hayek himself observes, a truly (i.e., Anglo-American) individualistic society is so conformist in its demeanor that people with a Germanic individualistic background usually find it very disturbing. ${ }^{172}$ This conformism, however, is said to have a libertarian core, since it grows from the awareness that if conventions did not govern conduct coercion would have to step in. It also reflects a humble recognition of the wisdom of inexplicable traditions. Conformity and a habit of compliance guarantee the "smooth working of an individualist system". ${ }^{173}$ Economic individualism and the conformism that makes people predictable seem to go together well.

\section{Functional and organic individualism}

Not by accident, in presenting and defending the conventionalism of an individualistic society as a palatable alternative to coercion, Hayek reasons from a perspective that is interested in allocating the task of conducting oneself and of controlling or stimulating the conduct of others. Conduct that

\footnotetext{
170 See ibid. at 5.

171 See ibid. at 11.

172 See ibid. at 25-26.

173 Ibid. at 26.
} 
is aimed at controlling one's own conduct and that of others is the subject of management and governance (or "governmentality", ${ }^{174}$ using Foucault's parlance). ${ }^{175}$ The attendant art of government is essentially concerned with "answering the question of how to introduce economy-that is to say, the correct way of managing individuals, goods, and wealth within the family $[\ldots]-[\ldots]$ into the management of the state." ${ }^{176}$ One core question, in this context, becomes how much governing is to be exercised either by public authorities or by individuals. ${ }^{177}$ The not so trivial presupposition is, of course, that "self-interest" will motivate individuals to govern the more unruly parts of their soul and to behave rationally. ${ }^{178}$ Once they do, they become calculable.

As Foucault has reminded us, it is, in fact, the recurrent strategy of political economy to confront governments with the question whether they are governing too little or too much. ${ }^{179}$ The question is asked with an eye to an objective. As a practice of governing that gives rise to specific forms of self-

\footnotetext{
${ }^{174}$ See Michel Foucault, 'Governmentality' In his Power (ed. J.D. Faubion, trans. R. Hurley et al, New York: New Press, 2000) 201-222, at 219-221.

175 See Foucault, 'The Subject and Power' In Power, note 174, 326-349 at 341. "Government", in the sense relevant to Foucault's project covers "[...] not only the legitimately constituted forms of political or economic subjection but also modes of action, more or less considered and calculated, that were destined to act upon the possibilities of action for other people."

176 Foucault, note 174 at 207.

177 It should not come as a surprise, hence, that Hayek admits, openly, that a liberal society is, in a sense, also "planned", however, planned in a manner that gives ample room to the unplanned working of the competitive order. See Hayek note 43 at 26-27, 36.

178 The most fundamental challenge is, as we have known since Nietzsche's Genealogy of Morals, to create a being that conceives of itself as the bearer of a long-term self-interest. See his Zur Genealogie der Moral. Eine Streitschrift (1887), Studienausgabe, note 150, vol. 5 at 292-293. The question has also drawn the attention of analytic moral philosophy and of "governmentality" studies. See Derek Parfit, Reasons and Persons (Oxford: Oxford University Press, 1986). Theorists taking their cue from Foucault call that which constitutes the subject as a self-governing and responsible agent "bio-power". See Barbara Cruikshank, The Will to Empower: Democratic Citizens and Other Subjects (Ithaka \& London: Cornell University Press, 1999) at 41: "[...] [B]iopower operates to invest the citizen with a set of goals and self-understandings, and gives the citizen-subject and investment in participating voluntarily in programs, projects, and institutions set up to 'help' them."

179 See Foucault, note 72 at 17.
} 
reflection, political economy and its techniques of government are supposed to serve the overall welfare of the population. ${ }^{180}$

If Foucault is not mistaken, political economy generates limitations on raison $d^{\prime}$ État that are intrinsic to it. ${ }^{181}$ They are not extrinsic in the manner in which the norms of public law are, which established limits that can be highly inconsistent with the pursuit of governmental objectives. Rather, the raison d'État of political economy rests on achieving the best overall aggregative effects for the population, a matter which is supposed to be good for the state. ${ }^{182}$ One encounters reasoning underpinning the modern raison d'État where the issue is how much or how little state activity is necessary for the benefit of the population. From this perspective, one can examine the role of the individual and ask the question of how much individual initiative is desirable in light of the overall social net result; what in light of this overall result the task of public authorities might be and how much initiative is to be left to individuals.

Certainly, I should offer apologies for introducing at a very late stage of this paper a distinction that may seem like a desperate attempt on the part of the author to make his text aesthetically congenial to analytic philosophy. Nevertheless, I believe it may be very helpful to perceive Hayek's individualism as a functional - in contrast to an organic - manner of putting the individual at the center. Individual freedom and empowerment are evaluated from a functional perspective if their realization is viewed as desirable with regard to what they contribute to some overall state of affairs. It should not come as a surprise that liberal political economy is the mainstay of this form of individualism. In fact, as a way of thinking it is congenial to

180 See Foucault, note 174 at 211, 219; note 72 at 21 . According to Foucault, the governing state is the successor to the state of the disciplinary society.

181 See Foucault, note 72 at $13,15$.

182 See ibid. at 15 . The old raison d'État of the police state was merely concerned about strengthening the state apparatus. 
how pre-modern political thought conceived of liberty in terms of plural "liberties". People enjoy their liberties inasmuch as these are necessary to fulfill certain social functions. ${ }^{183}$ Liberty as such, by contrast, is not an end, let alone an end in itself. The overall aim is the welfare of society. ${ }^{184}$

By contrast, organic individualism ${ }^{185}$ pays heed to how the individual is conducive to the weal of the whole and vice versa the whole conducive to the good of the individual. Most importantly, the individual good is not minted in the currency used for calculating the good of the whole. In other words, it cannot be expressed-at any rate not exclusively-in monetary terms. Organic individualism, in its most articulate form, limits the domain of money for the sake of the pursuit of other goods. ${ }^{186}$

Liberal political economy, in order to be appealing to individuals, must try to pass as organic individualism despite its thoroughly functional orientation. An indication that it fails at this is that it cannot get any further than to conceive of freedom qua freedom of choice. That freedom also involves identification and commitment cannot be accounted for by it. It really does not know what to do with the idea that persons are a law unto themselves.

This is not to say, however, that functional individualism could not become organic without losing its basic orientation. Changing the way of thinking cannot bring about such a transformation. It presupposes a change in the

\footnotetext{
${ }^{183}$ See Dieter Grimm, Recht und Staat der bürgerlichen Gesellschaft (Frankfurt aM: Suhrkamp, 1987) at 39-40.

184 In the case of Hayek, this is evident whenever he described, almost with a hint of Schadenfreude, how individual planning and forsight can be thwarted by the incidence of innovation or suddendly shifting consumer demand. The ultimate value of the economic system is "what others deem to be useful" and to reward individual effort and to respect choice. See Hayek, note 43 at $92-93$.

185 I should alert readers to the fact that the designation "organic individualism" is used differently by Roderick T. Long, who uses it to classify strands of individualistic philosophy that see individuals as essentially related to one another. See his 'The Classical Roots of Radical Individualism' (2007) 24 Social Philosophy and Policy 262-297.

186 See, as is well known, Michael Walzer, Spheres of Justice: A Defence of Pluralism and Equality (Oxford: Blackwell, 1983).
} 
relation of self to self. Social reality is more adaptive than theory. Functional individualism becomes organic when being a fully functional individual it what individuals truly want to be. This happens as soon as the individual good becomes absorbed by the functional requirements of political economy, that is, when all that individuals expect from life is to be rewarded, even if without real merit, ${ }^{187}$ for the usefulness that their conduct might create for others. This means, most adequately understood, that functional individualism becomes organic if people conceive of their lives from an entrepreneurial point of view. ${ }^{188}$ Once the individual good is no longer outside the market and no longer expressed in anything else than the amassing of wealth, functional individualism ascends to organic height on the basis of the self-understanding of individuals.

It becomes possible, then, to imagine a functional form of emancipation, that is, emancipation from being dysfunctional, or, put differently, emancipation in the state of liberalization and privatization.

With that we can turn to empowerment.

\section{Full-bodied empowerment}

The most remarkable feature of "empowerment" is that, as a slogan, it has advanced since the 1960s to the level of a universal recipe against a variety of human ills. ${ }^{189}$ Not surprisingly, the term is used evocatively for the empowerment of groups (e.g., ethnic groups, women) as well as individuals ${ }^{190}$

\footnotetext{
187 On the constitutive role of luck, see Hayek, note 43 at 77.

188 According to Cruikshank, note 178 at 39, Theresa Funicello describes this phenomenon as ,the professionalisation of being human".

${ }^{189}$ See Julian Rappaport, 'The Power of Empowerment Language' (1986) 16 Social Policy 15-21 at 17-18; Cruikshank, note 178 at 68.

190 See Bröckling, note 74 at 185, 189.
} 
or in order to mobilize resistance as well as to encourage the development of entrepreneurship. ${ }^{191}$ Empowerment has become a darling token of both the left and the right. Moreover, empowerment can carry a communitarian connotation that promises to reconcile reinvigorated individualism with solidarity. In this usage, empowerment designates individuals and groups establishing closer connections with organizations. ${ }^{192}$

In its application to both individuals and groups, empowerment is consistently about activation ${ }^{193}$ and encouraging people to govern themselves. ${ }^{194}$ More precisely, it is about activating some "potential" that is supposedly lying dormant owing to adverse social circumstance. Classical liberals seem to have believed that buried capabilities for activity would automatically rebound as soon as repression stops, in particular, the ability and the interest on the part of humans to take their life into their own hands. ${ }^{195}$ While the old subject of liberalism was believed to be driven by its desire for independence, the modern subject of empowerment is deemed to require stimulation or encouragement, in particular where staying passive promises to reap small benefits. ${ }^{196}$ The old subject of liberalism, once emancipated, enjoys its freedom. For the subjects of empowerment an act of emancipation is not enough. Even after emancipation they may remain vulnerable and weak. Their situation is characterized by widespread apathy. ${ }^{197}$ They need to be, first, identified as a group sharing a common interest, and, second, activated on the basis of some empowering

\footnotetext{
191 See Cruikshank note 178 at 67-68.

192 See Stephanie Riger, 'What's wrong with Empowerment?' (1993) 21 American Journal of Community Psychology 279-292 at 290; Cruikshank, note 178 at 89, 99.

193 See Bröckling, note 74 at 192, 210.

194 See Cruikshank, note 178 at 39.

195 See on this feature of liberal individualism already John Dewey, 'Individualism: Old and New', The Later Works, 1925-1953 (ed. J. A. Boydston, Carbondale: Southern Illinois University Press, 1984, vol. 5: 1929-1939, at 78-79.

196 See, the telling story about the career of empowerment in the course of the Community Action Program, which was part of the strategy of the war on poverty, in Cruikshank, note 178 at 67-80. 197 See ibid. at 73.
} 
intervention, which will draw on sociological and psychological expertise. ${ }^{198}$ The old subject of liberalism is capable of standing on its own feet if only it is allowed to do so. This is not the case for the subject of empowerment. It is habitually weak.

Undoubtedly, the subject of empowerment is also a liberal subject, for it has rights. However, it no longer has the guts to exercise them. For example, it does not organize political resistance ${ }^{199}$ or voluntarily contribute fresh ideas to the success of the business. Hence, it needs to be trained and counseled in order to rise to its own feet. ${ }^{200}$

The very fact that subjects of empowerment are in a situation of disempowerment already indicates that they have so far lacked the confidence, stamina, courage or social intelligence to pull themselves together and to discover their strength. Empowerment is the antidote to lethargy and acquiescence, but not a remedy for unequal legal status. In a social context, overcoming lethargy and resignation typically involves participation in processes of common problem solving. ${ }^{201}$ In the case of social policy, this means that people have to be assembled in constituencies and made to plan their own welfare. ${ }^{202}$

As a word, "empowerment" has become a standard inventory of a variety of vocabularies, ranging from psychology, management, consulting to some languages of political dissent. ${ }^{203}$ Its widespread appeal-and the widespread longing for empowerment-seems to suggest that diagnosing vulnerability

\footnotetext{
198 According the Cruikshank, ibid. at 25, 72, 122, "the will to empower" is recognisable in the complaint that citizens (or employees) are apathetic and disinterested.

199 This appears to have been the perception of "the poor" in the United States during the Johnson administration. See ibid. at 75-78

200 See ibid. at 97.

201 See Bröckling, note 74 at 188.

202 See Cruikshank, note 178 at 74-77. As Cruikshank (75) points out, the empowering agents often have their own views of what the interests of the subject to be empowered are. The result is a clash of "the subjectivity of citizens with their subjection".

203 See Bröckling, note 74 at 182-186.
} 
and weakness have come to play an increasingly prominent role in the interpretation of social experience. ${ }^{204}$ Seen from Marx's perspective of human emancipation, this is indicative of a process of "individualisation". If everyone is fending for him- or herself, everyone must feel weak.

The cure to overcoming weakness is believed to lie in the experience of actively altering one's situation. In this context, the discourse of empowerment suggests that the problems need to be whittled down to a scale at which the subjects of empowerment can solve them. Large ambitions create a discouraging sense of futility. Since empowerment basically acts upon the consciousness of the subjects to be empowered it is essential to help them discover strategies of self-help. ${ }^{205}$ Success at even small increments of empowerment exercises a positive re-enforcing effect on the self-esteem ${ }^{206}$ of the subjects to be empowered. More growth is possible on the basis of small beginnings. ${ }^{207}$

\section{One size fits all}

Evidently, empowerment is at odds with ambitious visions whose pursuit would require rebellion or revolution. Since these notoriously seem to be either unrealistic or dangerous a commitment to large-scale transformations often serves as a rationalization for not getting a hand on smaller problems. Moreover, the empowering subject does not-in marked contrast to a vanguard party-appear in the position to assert the objective interest of a class even vis-à-vis the individual members of this class. It is not the case,

\footnotetext{
204 See Bröckling, note 74 at 201.

205 See Cruikshank, note 178 at 70-71.

206 On the self-esteem movement of the 1980s, see Cruikshank, note 178 at 88-95. The idea appears to have been that lack of self-esteem is the cause of all social ills. Of course, there was no proof for this.

207 See the references in Bröckling, note 74 at 188.
} 
hence, that the subjects to be empowered perceive the knowledge that they should have of their situation and their interests represented in the knowledge of their empowering leaders. ${ }^{208}$

The standard situation that appears to call for empowerment is competitive. Empowerment does not begin with a moral examination of the current state of affairs. Nor does it conclude with what has to be done in order for justice to prevail. It does not ask whose fault it might have been that things are the way they are; it is not of interest, in particular, to establish that the subject of empowerment may be responsible for its disempowerment. ${ }^{209}$ Rather, empowerment is essentially forward-looking in its drive to activate subjects to mobilize themselves.

Empowerment is, therefore, the reverse of human emancipation. The competitive situation is left in place. The redistribution of power is not the issue. ${ }^{210}$ What matters, rather, are discrete and context-specific efforts at leveling power asymmetries. This begins with making people feel more powerful by giving them clues as to where the source of their strength might lie. ${ }^{211}$ The idea is that once people feel better about themselves they will realize what they are able to do. Not surprisingly, the technique of empowerment is kindred to psychological counseling rather than political leadership. ${ }^{212}$ Liberation is a matter of working on the psyche, guided by experts, and not of political strategy. ${ }^{213}$

\footnotetext{
208 For a critique of this Leninist conception of the party, as articulated by Lukács, see Jürgen Habermas, Theorie und Praxis: Sozialphilosophische Studien (2d. ed., Frankfurt aM: Suhrkamp, 1971) at 40-41.

209 See ibid. at 201-202.

210 See ibid. at 193.

211 See ibid. at 201, 203.

212 This is evident in the writings of one of the first advocates of what would become "empowerment", Paulo Freire, whose pedagogy of the oppressed was sharply opposed to social policy that merely wanted to assist people. See 213 See Cruikshank, note 178 at 92.
} 
Empowerment is remarkably universal. Above all, it cannot be reconciled with the idea that some may simply have to live less active lives than others by virtue of who they are. Apparently, this is what remains of the idea of justice, namely, an equal entitlement to activation. Disabled people have a claim to empowerment. This means they have to be given an opportunity, and the wherewithal, to participate in a life form that is essentially active. Their entitlement is functional. The right to be activated is functionally necessary in order to be recognized as an equally active participant, for if one were not one would be registered as abnormal pursuant to the ruling standards of social distinction. The entitlement to activation is a functional correlate of a duty towards oneself to earn social recognition subject to the conventional terms established in societies. Moreover, fulfilling the entitlement to be spurred into activity is also believed to be good for society. A democratic society depends on the participation of its citizens and on their ability to conduct themselves in communication with others. ${ }^{214}$

The universal entitlement to be thrown into the mode of self-activation is also deemed to be a strategy for reconciling individuals with larger organizations. Lethargic employees are deemed to be "empowered" when managers have succeeded at motivating them to take a more active part in their business. Even in this context it is taken for granted that it is desirable to participate and that there is no deeper conflict of interest between individuals and organizations. ${ }^{215}$ The premise appears to be that playing a role in the success

\footnotetext{
214 See ibid. at 91.

215 This prestabilised harmony is captured in the otherwise rather fuzzy Foucauldian term of "bio-power". See Cruikshank, note 178 at 39-40: "[...] [B]io-power, through the administration and regulation of life and its needs enacts the good of all society upon the antisocial bodies of the poor, deviant and unhealthy. It seeks to unite the interests of the individual with the interest of society as a whole."
} 
of the latter is important for experiencing personal success. ${ }^{216}$ Identification with the business is what is supposed to bridge the gap.

Given that empowerment has such a variety of applications, it appears to be a universal strategy for reconciling persons with their social context. ${ }^{217}$ It seems to be the one and only panacea that is applicable everywhere. Nevertheless, empowerment betrays a rather liberal outlook. The empowering agent does not have to have a vision of what the social situation of the subject to be empowered would have to be like in the future. The agent does not shoulder any responsibility. She is not part of the group to be empowered. All that the agent has to do is to stimulate the capacity for action. She does not have to be committed to any cause. She does not have to make an attempt to change the overall context of action. Since empowerment is played out in competitive situations the context will likely change as a result of acts by the empowered subject. The agent does not have to take sides. Empowerment is apolitical. It is a technique of activating the disheartened and overwhelmed.

\section{Empowerment in the European Union}

Even though "empowerment" appears to signify a variety of things, its various meanings revolve around a non-trivial core. The overall goal is to kick people who feel weak out of an habitual attitude of acquiescence. Activation goes beyond the level of rights and affects real capabilities. It is reinforced through the experience of problem-solving. Since empowerment involves in one way or another participation, it supposedly reconciles people with their

\footnotetext{
216 Another connection between the interest of society and the interest of the individual is that society benefits from empowered individuals who have learned to conduct themselves and that they can join forces in order to become even more powerful. See ibid. at 91, 97.

217 See Bröckling, note 74 at 193.
} 
social environment. In the course of participation they begin to identify with the goals of an organization or of a community.

The composite of meanings of empowerment can be encountered also in the context of the European Union. There is, to begin with, talk of empowerment in the sense of stakeholder participation in the context of policy formation. This was the clear message of the proposed new strategy of generating ideas for "social innovation" through the interaction with affected groups. ${ }^{218}$ Stakeholder involvement is also deemed important when it comes to developing strategies for a secure information society. In this context, empowerment appears as a synonym for the participation of public (e.g., the Member States) and private actors. ${ }^{219}$

Likewise, "women's empowerment" is a topic that emerges in the context of development policy. ${ }^{220}$ The requisite EU Action Plan states that "not only civil and political rights but also the implementation of economic, social, cultural and labor rights [...] are vital for achieving women's empowerment."221 The emphasis on implementation suggests, again, that empowerment concerns the social effect of the enjoyment of rights and not merely their formal recognition. Empowered women draw their strengths from the awareness that their rights are fully respected. Similarly, the EU speaks of the economic empowerment of women and means that they become economically active as either self-employed or employees..$^{222}$

\footnotetext{
218 See above note 4.

219 See Commission Communication, 'A strategy for a Secure Information Society - "Dialogue, partnership and empowerment"', SEC(2006) 656.

${ }^{220}$ See Commission Communication, 'Strategy for equality between women and men 2010-2015', $\operatorname{SEC}(2010) 1079$ at 9.

221 European Commission, 'EU Plan of Action on Gender Equality and Women's Empowerment in Development 2010-2015', http://www.devpractitioners.eu/fileadmin/user_upload/EU_GEAP.pdf at 7. 222 See ibid., at 9.
} 
That empowerment looks beyond the mere legal status and designates the actual capabilities of people emerges clearly from how the Commission proposes to "empower consumers". It concerns the "ability of consumers" to understand their choices. Consumers should, according to the Commission, be in such a position even where there is no concern that businesses have concealed information or engaged in any other form of misleading behavior. ${ }^{223}$ Consumer empowerment is identified with "the levels of consumer education, information, understanding, consumer literacy/skills, awareness and assertiveness". ${ }^{224}$ Remarkably, smart consumer behavior is linked to the improvement of markets since misinformed consumer choice gives rise to an inefficient allocation of resources: ${ }^{225}$

Efficient and responsive consumer markets across the economy are key drivers of competitiveness and citizen's welfare. They need empowered consumers able to make informed choices and quickly reward efficient operators. Markets where consumers are confused, misled, have no access, or have little choice will be less competitive and generate more consumer detriment, at the cost to the efficiency of the overall economy.

Putting it bluntly, widespread consumer stupidity creates an externality for the few smart consumers who have to but put up with incompetent businesses dominating the market.

Finally, "empowerment" appears at a key place of the so-called Renewed Social Agenda. It states that the means to achieve the fundamental goals of Union policy have to be adjusted towards "empowering and enabling individuals to realize their potential while at the same time helping those who are unable to do so." 226 Despite its high level of generality, the message is relatively clear. Social objectives are to be attained by activating individuals-

223 See Commission Communication, 'Monitoring consumer outcomes in the single market: the Consumer Markets Scoreboard' at 5 (para. 19)m 8 (para. 35)

224 See ibid at 7 (para. 32).

225 See ibid at. 3 (para. 6).

226 Commission Communication, 'Renewed social agenda: Opportunities, access and solidarity in the 21st century', SEC(2008) 2184 at 3. 
or rather, by encouraging them to self-activate. Those who cannot be galvanized count as quasi-disabled and are, owing to their disability, eligible for additional support. The Agenda stresses, among other things, the necessity to provide access for all individuals to the means of achievement. But achievements do not exist for the individual alone. The Agenda is quite clear that the triadic strategy of "opportunity, access and solidarity" is supposed to serve the Union's economic objectives. It says that education and "investing in human capital" are important to facilitate labor market participation and social inclusion. They are also deemed to be critical to enhancing the competitiveness of the European economy as a whole.227

This is a manifestation of the functional individualism mentioned above. Nothing, indeed, could be further removed from the ideal of human emancipation than the sketch of the ideal individual employee that the Commission seeks to breed through the channels of the open co-ordination process. In a "rapidly changing world", Commission says, people need to avail themselves of opportunities at different stages of their lives. This means that they have to be committed to "lifelong learning and ongoing renewal of skills attuned to present and future labor market needs". ${ }^{228}$ And, of course, as a captatio benevolentiae "entrepreneurship" is mentioned in passing.

Permanent activation in the pursuit of adaptation is what appears to be meant by empowerment in the Union.

227 See ibid. at 9.

228 Ibid. 


\section{Conclusion: From Rosa Luxemburg to Steven Jobs}

The European strategy of emancipation that has been successful in the twentieth century was committed to creating negative freedom from the market. Culturally, it must have been based on the convergence of the proletarian and pre-protestant/bourgeois desire to minimize the sway of work and profession over human life. It was a world where one did not have to be healthy but could afford to be sick; where jobs would be available even for people with low ambition; where people were looking forward to retirement and had no problem with leaving their desks for the next generation.

Empowerment reverses this orientation. It "emancipates" from the passivity that may be the last refuge of those whose life lies outside the busyness of economic dealings. In other words, while the welfare state emancipated people from the adverse effects of the imperative of inclusive fitness, empowerment emancipates people from their lack of fitness. From the perspective of markets, it goes to the root of the problem. The previous attempt of emancipating people from the negative consequences of their unfitness involved the recognition that it is not a defect if one is ill, old, slow, dim-witted or relatively lazy. Activating the inactive, by contrast, revokes this recognition.

Both human emancipation and the negative liberty from markets require a collective effort and are supposed to be a common achievement. Against this background, empowerment is quite a paradoxical ideal. It presents emancipation, first, in individualized form and, second, as immanent to the market. Empowerment retracts the liberating impulse into the market. It is the economic emancipation from the market, which is co-extensive with the idea that it is possible to rise above the market from within. Not by accident, the figure that is most admired in a market economy is the participant that 
succeeds at defying market pressures. This is the entrepreneur. The entrepreneur overcomes the rational shackles of the market calculation. Entrepreneurs do not merely react to the demands made by others. They take the lead. True entrepreneurs influence factors that are beyond the control of ordinary market participants because they are able to divine the desires of consumers at a time when these consumers do not yet have the slightest idea that they are going to have them. In a sense, they have the powers equivalent to the vanguard party.

Rosa Luxemburg believed that small-scale protest and industrial action would be the school for the working class to realize that their freedom depends on their solidarity. ${ }^{229}$ This is continuous with the idea of human emancipation. European humanity has taken leave of this idea. Today, rather, the hero of emancipation is the innovative entrepreneur who succeeds at establishing a monopoly. The entrepreneur is the monopolist who deserves to be in this position by virtue of ingenuity and charisma. Entrepreneurs are more than, and different from, rationally calculating managers. ${ }^{230}$ They are driven by unconventional ideas and tireless in moving forward. Entrepreneurs have an edge, supreme intuition, stamina, instinct and luck. The have courage, and owing to their courage they have the power to change markets by market means. Their success is manifest in how they stamp out others. They, if anyone, represent the promise of ancient liberty in individualized economic terms. They are, in other words, the embodiment of the empowered individual.

Rather than the general strike, the entrepreneur is the "myth" of our time. It is a strange projection into the individual of what people could do if only they were still able to exercise the freedom of the ancients.

229 See above note 48.

230 See Weber, WuG 129. 


\section{Recent LEQS papers}

Kleine, Mareike. 'Trading Control: National Chiefdoms within International Organizations' LEQS Paper No. 59, March 2013

Aranki, Ted \& Macchiarelli, Corrado. 'Employment Duration and Shifts into Retirement in the EU' LEQS Paper No. 58, February 2013

De Grauwe, Paul. 'Design Failures in the Eurozone: Can they be fixed?' LEQS Paper No. 57, February 2013

Teixeira, Pedro. 'The Tortuous Ways of the Market: Looking at the European Integration of Higher Education from an Economic Perspective' LEQS Paper No. 56, January 2013

Costa-i-Font, Joan. ' Fiscal Federalism and European Health System Decentralization: A Perspective' LEQS Paper No. 55, December 2012

Schelkle, Waltraud. 'Collapsing Worlds and Varieties of welfare capitalism: In search of a new political economy of welfare' LEQS Paper No. 54, November 2012

Crescenzi, Riccardo, Pietrobelli, Carlo \& Rabellotti, Roberta. 'Innovation Drivers, Value Chains and the Geography of Multinational Firms in European Regions' LEQS Paper No. 53, October 2012

Featherstone, Kevin. 'Le choc de la nouvelle? Maastricht, déjà vu and EMU reform' LEQS Paper No. 52, September 2012

Hassel, Anke \& Lütz, Susanne. 'Balancing Competition and Cooperation: The State's New Power in Crisis Management’ LEQS Paper No. 51, July 2012

Garben, Sacha. 'The Future of Higher Education in Europe: The Case for a Stronger Base in EU Law' LEQS Paper No. 50, July 2012

Everson, Michelle. 'A Technology of Expertise: EU Financial Services Agencies' LEQS Paper No. 49, June 2012

Cherrier, Nickolas. 'EU Diplomacy at 27: United in Diversity?' LEQS Paper No. 48, May 2012

White, Jonathan. 'Parallel Lives: Social Comparison Across National Boundaries' LEQS Paper No. 47, January 2012

Meyer, Niclas. 'Political Contestation in the Shadow of Hierarchy' LEQS Paper No. 46, January 2012

Hyman, Richard. 'Trade Unions, Lisbon and Europe 2020: From Dream to Nightmare' LEQS Paper No. 45, December 2011

Wagner, Peter. 'The democratic crisis of capitalism: Reflections on political and economic modernity in Europe' LEQS Paper No. 44, December 2011

Chalmers, Damian \& Chaves, Mariana. 'The Reference Points of EU Judicial Politics' LEQS Paper No. 43, September 2011

Hassel, Anke. 'The paradox of liberalization - Understanding dualism and the recovery of the German political economy' LEQS Paper No. 42, September 2011 


\section{LEQS}

European Institute London School of Economics Houghton Street WC2A 2AE London

Email: euroinst.LEQS@lse.ac.uk

http://www2.lse.ac.uk/europeanInstitute/LEQS/Home.aspx

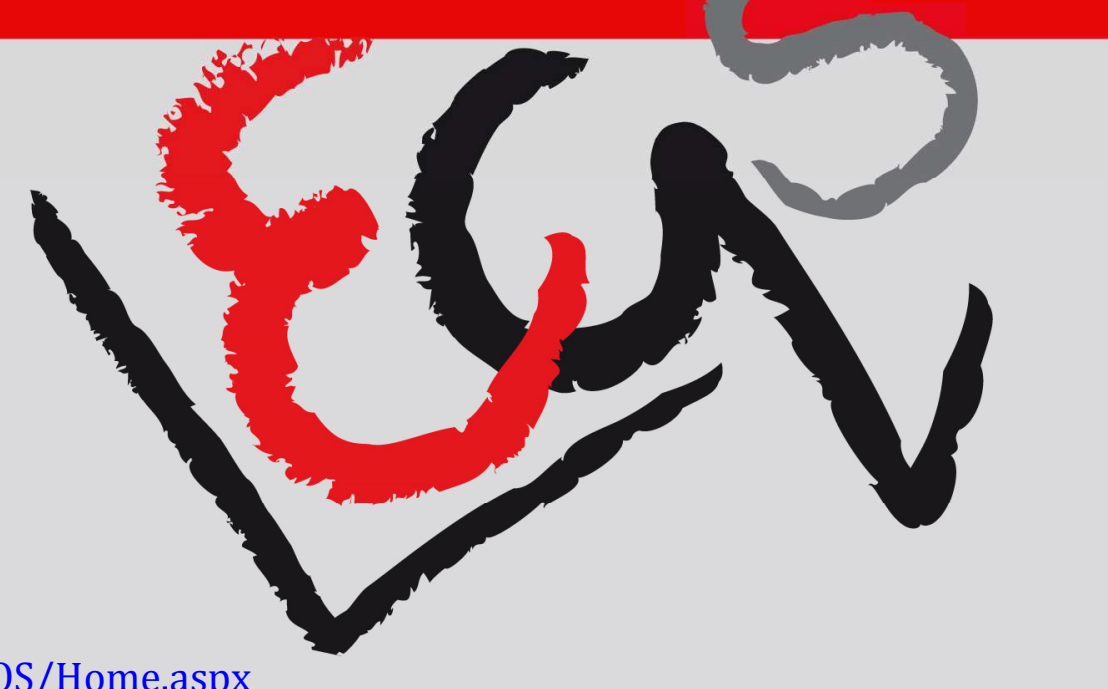

